\title{
Modelling the chemically aged and mixed aerosols over the eastern central Atlantic Ocean - potential impacts
}

\author{
M. Astitha ${ }^{1}$, G. Kallos ${ }^{2, *}$, C. Spyrou ${ }^{2}$, W. O'Hirok ${ }^{1}$, J. Lelieveld ${ }^{1,3}$, and H. A. C. Denier van der Gon ${ }^{4}$ \\ ${ }^{1}$ Energy, Environment and Water Research Centre, The Cyprus Institute, Nicosia, Cyprus \\ ${ }^{2}$ University of Athens, School of Physics, Division of Environmental Physics-Meteorology, Bldg PHYS-V, \\ 15784, Athens, Greece \\ ${ }^{3}$ Max Planck Institute for Chemistry, Becherweg 27, 55128 Mainz, Germany \\ ${ }^{4}$ TNO Built Environment and Geosciences, Princetonlaan 6, P.O. Box 80015, 3584 CB Utrecht, The Netherlands
}

Received: 15 January 2010 - Published in Atmos. Chem. Phys. Discuss.: 23 February 2010

Revised: 26 May 2010 - Accepted: 10 June 2010 - Published: 1 July 2010

\begin{abstract}
Detailed information on the chemical and physical properties of aerosols is important for assessing their role in air quality and climate. This work explores the origin and fate of continental aerosols transported over the Central Atlantic Ocean, in terms of chemical composition, number and size distribution, using chemistry-transport models, satellite data and in situ measurements. We focus on August 2005, a period with intense hurricane and tropical storm activity over the Atlantic Ocean. A mixture of anthropogenic (sulphates, nitrates), natural (desert dust, sea salt) and chemically aged (sulphate and nitrate on dust) aerosols is found entering the hurricane genesis region, most likely interacting with clouds in the area. Results from our modelling study suggest rather small amounts of accumulation mode desert dust, sea salt and chemically aged dust aerosols in this Atlantic Ocean region. Aerosols of smaller size (Aitken mode) are more abundant in the area and in some occasions sulphates of anthropogenic origin and desert dust are of the same magnitude in terms of number concentrations. Typical aerosol number concentrations are derived for the vertical layers near shallow cloud formation regimes, indicating that the aerosol number concentration can reach several thousand particles per cubic centimetre. The vertical distribution of the aerosols shows that the desert dust particles are often transported near the top of the marine cloud layer as they enter into the region where deep convection is initiated. The anthropogenic sulphate aerosol can be transported within a thick layer and en-
\end{abstract}

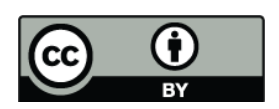

Correspondence to: G. Kallos (kallos@mg.uoa.gr) ter the cloud deck through multiple ways (from the top, the base of the cloud, and by entrainment). The sodium (sea salt related) aerosol is mostly found below the cloud base. The results of this work may provide insights relevant for studies that consider aerosol influences on cloud processes and storm development in the Central Atlantic region.

\section{Introduction}

Aerosols are complex mixtures of atmospheric constituents that play a role in many environmental and climate issues, ranging from air quality and human health impacts to potential effects on the hydrological cycle (Ramanathan et al., 2001; Lau and Kim, 2007). Aerosols originate from natural (desert dust, sea salt particles) and anthropogenic sources (urban, industry, biomass burning), and can travel long distances from Europe and Africa reaching the Central Atlantic Ocean (Prospero et al., 2001; Kaufman et al., 2002b; Formenti et al., 2003; Kallos et al., 2006, 2007). Chemical aging of dust aerosols occurs through heterogeneous interactions between particles and gases of different origin. The aged dust particles can have distinctly different physico-chemical properties and hygroscopicity than the primary emitted particles. For example, desert dust particles being initially not very soluble and ineffective cloud condensation nuclei $(\mathrm{CCN})$ can become coated with soluble material turning them into effective CCN (Andreae et al., 1986; Levin et al., 1996, 2005). On the other hand, non-coated and less hygroscopic dust particles can act as ice nuclei (IN) (Levin and Cotton, 2009 and references therein). Anthropogenic aerosols can cause

Published by Copernicus Publications on behalf of the European Geosciences Union. 
a direct radiative forcing of climate (Forster et al., 2007 and references therein), and, acting as CCN, IN or by locally absorbing solar radiation, can interact with clouds and precipitation, thus causing indirect climate effects (Ramanathan et al., 2001; Denman et al., 2007). The links between aerosols, radiation, clouds and precipitation are a main subject of theoretical, experimental and modelling studies during recent years. Many of these studies were summarized in the IPCC 4th Assessment Report (Forster et al., 2007); yet major uncertainties remain.

During the warm season, polluted air masses from Europe and the Mediterranean region can be transported towards the Inter-Tropical Convergence Zone (ITCZ, located over N-Africa) and subsequently towards the Central Atlantic Ocean by the trade wind easterlies (Millan et al., 1997; Kallos et al., 1998, 2007; Gangoiti et al., 2006 and references therein). The aerosols entering the Central Atlantic region, where intense convective activity can develop, may influence cloud formation through their CCN and IN activity depending on their number, size and chemical composition. Furthermore, particulate air pollution, including desert dust, has been indicated as potentially reducing the sea surface temperature (SST) of the Mediterranean Sea (Lelieveld et al., 2002) and the Central and Northern Atlantic Ocean (Lau and Kim, 2007; Evan et al., 2009), and the latter affecting tropical cyclone activity (Evan et al., 2006). Aerosol and CCN measurements near the Azores (Garrett and Hobbs, 1995) have shown that polluted continental air can alter cloud structures through enhancements in the CCN number concentrations and shifts in the droplet size spectra. More recent field campaigns, such as the African Monsoon Multidisciplinary Analysis (AMMA), were dedicated to understanding the role of the African monsoon (Redelsperger et al., 2006) in the West Africa region. A continuation of the AMMA project has been the field campaign in the East Atlantic (NASAAMMA) to investigate the linkage between the African easterly waves, the Saharan Air Layer and tropical cyclogenesis (Zipser et al., 2009). Although this is a complex and controversial topic, encompassing a wide range of scales of atmospheric (micro)physics, chemistry and dynamics, there is general agreement that changes in aerosols can affect clouds and precipitation. The sign and extent of the aerosol influences is subject of ongoing field and modelling studies.

The subject of this work is the characterization of the aerosols over the Central Atlantic Ocean in terms of number and size distribution and chemical composition. The methods used involve chemistry-transport modelling, the use of aerosol measurements and data retrieved from satellite observations, focusing on August 2005, a month with intense hurricane and tropical storm activity over the Atlantic Ocean. Implementing state-of-the-art regional modelling systems and satellite retrievals may be considered as a first step towards the characterization of aerosols and their possible climate effects. It should be noted that the modelling tools used here are not suited for studying the intricate mech- anisms of aerosol/radiation/cloud processes, which therefore are not directly addressed. The focus of this work is on the chemical composition and number concentration of the aerosols entering the eastern Central Atlantic Ocean tropical storm genesis region. The models selected for this study, the simulation period chosen and the input data implemented in the model are detailed in Sect. 2. In the subsequent section, the results are presented and discussed focusing on the number distribution of natural and anthropogenic aerosols near the cloud formation areas, and the final section presents the conclusions.

\section{Models and data used}

The modelling system used in the present study is the combination of the latest versions of the SKIRON/Dust model (Kallos et al., 1997, 2006, 2009; Nickovic et al., 2001) and the Comprehensive Air Quality Model with ExtensionsCAMx (Environ, 2006), with additions/improvements to the aerosol schemes (Astitha and Kallos, 2008). A recently updated version of the SKIRON/Dust model includes the treatment of dust particles using a lognormal size distribution partitioned into eight size bins from $0.1 \mu \mathrm{m}$ to $10 \mu \mathrm{m}$ diameter (Kallos et al., 2009). It also includes the online calculation of aerosol optical depth and its influence on radiative transfer by utilizing look-up tables (Kaufman et al., 2002a). Since the dust module is radiatively-dynamically coupled to the atmospheric model, prognostic meteorological calculations are expected to realistically treat the injection of dust into the lower atmospheric levels. The performance of the SKIRON/Dust model has been tested in several recent studies (Kallos et al., 2006, 2007; Astitha et al., 2008).

The Comprehensive Air Quality Model with ExtensionsCAMx (Environ, 2006) is a Eulerian chemistry-transport model that includes gas and aerosol chemistry, wet and dry deposition processes, aqueous phase processes, thermodynamic partitioning of the inorganic aerosols (Nenes et al., 1998) and secondary organic aerosol formation/partitioning. The CAMx model includes wet deposition processes using scavenging schemes for gases and aerosols. They treat the uptake of gases and particles as a function of rainfall rate, cloud water content, gas solubility and diffusivity and PM size. Particulate matter (PM) is irreversibly scavenged directly by all precipitation forms via impaction and by uptake into cloud water (liquid and ice) as condensation nuclei. All in-cloud PM mass exists in cloud water (i.e., no "dry" aerosols exist in the interstitial air between cloud droplets). The meteorological fields that drive the air quality simulations are taken from the SKIRON/Dust model in an offline mode, with a time resolution of one hour. There is no feedback from the air quality simulation (CAMx) to the meteorological model (SKIRON/Dust). Although the feedbacks of chemical composition changes in the atmosphere can be important in altering the predicted meteorological fields (Alpert 
et al., 1998; Perez et al., 2006; Spyrou et al., 2010), this could not be realized with the available modelling systems used for this study. An online atmospheric-chemistry modelling system would be the proper tool to investigate the above feedback effects, which is in development for future work. The version of CAMx implemented in the current study is an updated version of the original model. New features include processes that adopt the desert dust fluxes from the SKIRON/Dust model, impacts of dust optical depth on photochemical reactions, online production of sea salt and online heterogeneous reactions on the surface of dust particles.

The uptake of gaseous species by solid particulate matter is realized in two steps (Zhang et al., 1994; Dentener et al., 1996; Saylor, 1997; Bauer and Koch, 2005). The gas molecules are transported to the particulate surfaces by diffusion, then cross the interphase between the gaseous and particulate phases, and subsequently react at the solid surface. A first-order kinetic relationship is used to represent the change in gas and aerosol concentrations due to uptake on dust particles as shown in Eq. (1):

$$
\begin{aligned}
& \frac{d C_{g}}{d t}=-k_{g, r} C_{g} \\
& \delta_{g, r}=C_{g}\left(1-e^{-k_{g, r} d t}\right) \\
& C_{g}=C_{g}-\delta_{g, r} \\
& C_{\text {aero }}=C_{\text {aero }}+\delta_{g, r}
\end{aligned}
$$

Where $C_{g}$ is the gas concentration, $C_{\text {aero }}$ is the aerosol concentration and $k_{g, r}\left(\mathrm{~s}^{-1}\right)$ is the removal rate of species $g$ to a particle surface with radius $r$. Following the formulation by Fuchs and Sutugin (1970) and Saylor (1997) the removal rate is calculated as shown in Eqs. (2) and (3). The assumptions made for this calculation are that the particles are monodisperse, they have a spherical shape and the gas uptake is irreversible.

$k_{g, r}=\frac{4 \pi D_{g} r N_{r}}{1+f\left(K_{n}, \gamma\right) K_{n}}$

$f\left(K_{n}, \gamma\right)=\frac{1.333+0.71 K_{n}^{-1}}{1+K_{n}^{-1}}+\frac{4(1-\gamma)}{3 \gamma}$

where $K n$ is the Knudsen number, $D_{g}$ the gas-phase molecular diffusion coefficient in the air, $N_{r}$ the particle number density and $\gamma$ is the reactive uptake coefficient. The reactive uptake coefficient is usually determined through laboratory experiments or approximated based on in-situ field measurements and is different for each gas and solid material available for the uptake. For sulphur dioxide uptake at the surface of dust particles we have used the constant value $\gamma=10^{-4}$ according to a number of studies on this topic (Zhang and Carmichael, 1999; Goodman et al., 2001; Usher et al., 2002; Tang et al., 2004; Bauer and Koch, 2005). The uptake coefficients for the other reactions are: $\gamma\left(\mathrm{NO}_{2}\right)=10^{-4}, \gamma\left(\mathrm{HNO}_{3}\right)=0.1, \gamma\left(\mathrm{O}_{3}\right)=5 \times 10^{-5}$. Including a constant uptake coefficient is first order approximation for a more detailed numerical scheme to compute the coefficient as a function of temperature, humidity and the level of surface coverage of the particle by condensable species. However, we do not expect a high importance of this process. A schematic of the modeled reactions is given below:

$$
\begin{aligned}
& \mathrm{SO}_{2} \stackrel{\text { dust }}{\longrightarrow} \mathrm{DSO}_{4} \text { (aerosol) } \\
& \mathrm{NO}_{2} \stackrel{\text { dust }}{\longrightarrow} \mathrm{DNO}_{3} \text { (aerosol) } \\
& \mathrm{HNO}_{3} \stackrel{\text { dust }}{\longrightarrow} \mathrm{DNO}_{3} \text { (aerosol) } \\
& \mathrm{O}_{3} \stackrel{\text { dust }}{\longrightarrow} \mathrm{O}_{2}
\end{aligned}
$$

Another important new feature is the use of the desert dust fluxes from the SKIRON/Dust model. These fluxes are converted to emissions of crustal material and they are introduced into the CAMx model for the simulation set up. The mentioned new features are described in detail in Astitha and Kallos (2008). Astitha and Kallos (2008) also performed a statistical analysis of the model performance for the on-line sea salt production. It should be noted that organic aerosols (primary and secondary) are not accounted for in this study. Even though we acknowledge their significance in the atmospheric composition (Kanakidou et al., 2000), in this study we emphasize inorganic aerosols and desert dust and their interactions. This system is already complex to analyze, and the inclusion of organics in the aerosol mixture is associated with large uncertainties, and the analysis of their contribution is a subject for future work.

Information on the input data and configuration of the modelling system appear in Table 1 and are briefly discussed below. For the performed simulations with the SKIRON/Dust model, we used initial and lateral boundary conditions $\left(0.5^{\circ} \times 0.5^{\circ}\right)$ from the European Centre for MediumRange Weather Forecasts (ECMWF) at 16 isobaric levels. Nudging has been performed on the lateral boundaries. Also, daily SSTs are adopted from the ECMWF. The topography and vegetation input fields were obtained from the U.S. Geological Survey (USGS) $30 \times 30$ analysis dataset. The soil texture was taken from ZOBLER and FAO/UNESCO at $30 \times 30$ resolution. The model horizontal resolution applied is $0.24^{\circ} \times 0.24^{\circ}$, with 38 vertical levels up to $22 \mathrm{~km}$ altitude.

The chemistry-transport simulations with the CAMx model used the 3-D meteorological fields from the SKIRON/Dust model as input (wind, temperature, pressure, water vapour, clouds, precipitation, diffusivities). The initial and boundary conditions are temporally and spatially constant concentrations based on climatological data. For the gas-phase chemical reactions the CBIV (Carbon Bond IV) mechanism is chosen and for aerosol chemistry the multisection scheme (CMU) is used that includes ISORROPIA and RADM for the thermodynamics and the aqueous phase processes. The aerosol particles are partitioned into three size sections: $0.03-0.1,0.1-2.5$ and $2.5-10 \mu \mathrm{m}$. These sections were chosen in accordance with the sea salt production scheme, even though dust is produced from the SKIRON/Dust model using eight size bins. The emission fields necessary for the model simulations are obtained from various sources and are described below. 
Table 1. Configuration of the modelling systems.

\begin{tabular}{|c|c|}
\hline \multicolumn{2}{|r|}{ SKIRON/Dust modelling system } \\
\hline Input data & $\begin{array}{l}\text { ECMWF initial and lateral boundary conditions }\left(0.5^{\circ} \times 0.5^{\circ}\right) \text { on } 16 \text { isobaric levels; Daily SST from } \\
\text { ECMWF; topography }\left(30^{\prime \prime} \times 30^{\prime \prime}\right) \text { : US Geological Survey (USGS) dataset; vegetation }\left(30^{\prime \prime} \times 30^{\prime \prime}\right) \text { : USGS } \\
\text { dataset; Soil texture }\left(30^{\prime \prime} \times 30^{\prime \prime}\right)-\text { ZOBLER and FAO/UNESCO }\end{array}$ \\
\hline Horizontal resolution: & $0.24^{\circ} \times 0.24^{\circ}$ No of grid points: $294 \times 313$ \\
\hline No of vertical layers: & 38 (up to $22 \mathrm{~km}$ ) \\
\hline Simulation Period & 31 July-30 August 2005 \\
\hline \multicolumn{2}{|r|}{ CAMx v4.31 chemical transport model } \\
\hline Input Meteorological data & 3-D meteorological fields from SKIRON/Dust \\
\hline Input air quality data & Gridded initial and boundary conditions, time/space constant concentrations based on climatological data \\
\hline Input emission data & $\begin{array}{l}\text { Gridded area and point sources from TNO database }\left(0.25^{\circ} \times 0.125^{\circ}\right) \text {. Gridded area sources from GEIA } \\
\left(1^{\circ} \times 1^{\circ}\right) \text { (ww. geiacenter.org). Emissions from ships from EMEP database (www.emep.int). }\end{array}$ \\
\hline Horizontal resolution: & $0.5^{\circ} \times 0.25^{\circ} \quad$ No of grid points: $243 \times 237$ \\
\hline SW corner of the grid: & $(-60.25 \mathrm{~W},-5.125 \mathrm{~S}) \quad$ No of vertical layers: 24 (up to $10 \mathrm{~km})$ \\
\hline Chemical mechanism & $\begin{array}{l}\text { CB-IV with full aerosol chemistry (ISORROPIA, SOAP, RADM). CMU approach ( } 3 \text { size sections): } 0.03- \\
0.1,0.1-2.5,2.5-10 \mu \mathrm{m} \text {. Sea salt production. Heterogeneous uptake of gases on dust particles. }\end{array}$ \\
\hline Simulation Period & $1-30$ August 2005 \\
\hline
\end{tabular}

Because of the large spatial area required for the present simulations, ranging from Northern Europe to Southern Africa and from the Arabian Peninsula to the Western Atlantic Ocean, it was necessary to derive the emission inventory from a combination of available sources. Specifically, the emissions for the European region are from TNO (Netherlands Organisation for Applied Scientific Research) in $0.25^{\circ} \times 0.125^{\circ}$ horizontal analysis for the year 2000 (Visschedijk and Denier van der Gon, 2005); the emissions for the shipping sector are from the Convention on Long-range Transboundary Air Pollution-EMEP (Vestreng, 2003) and for the remaining areas they are adopted from the Global Emissions Inventory Activity (GEIA) database. Neither EMEP nor GEIA inventories cover the shipping sector in the central and southern Atlantic Ocean. This has been a disadvantage due to the absence of a more complete dataset at the time and it will lead to a possible underestimation of the modelled sulphates and/or nitrates in the area. To accomplish a uniform gridding of the different inventories, an interpolation scheme is used to re-grid the different resolutions of the databases. The emission input data include $\mathrm{SO}_{2}, \mathrm{NH}_{3}, \mathrm{CO}$, $\mathrm{NO}_{\mathrm{x}}$, Non-Methane Volatile Organic Compounds (NMVOC, speciated in seven species based on the requirements of the CBIV chemical mechanism) and isoprene.

The time-period selected for simulation is August 2005. This was a period of intense convective activity in the Central Atlantic Ocean region, accompanied with tropical storms, which in several occasions developed into hurricanes (Lau and Kim, 2007). During August 2005, two severe hurricanes (Irene, Katrina) and three tropical storms (Harvey, Jose, Lee) developed according to the National Hurricane Center, with more than 20 being identified for the period of June to
November 2005 (http://www.nhc.noaa.gov). This region experiences the long-range transport of pollutants from natural and anthropogenic sources during summer. Various studies have investigated the intercontinental transport of desert dust (Karyampudi, 1979; Perry et al., 1997; Karyampudi et al., 1999; Prospero et al., 2001; Kallos et al., 2006), the radiative influence of aerosols (Ramanathan et al., 2001; Lau and Kim, 2007; Evan et al., 2009) and the chemical composition of dust entering the Central Atlantic (Husar et al., 1997; Formenti et al., 2003; Zipser et al., 2009). In fact, this is only a subset of the studies performed for this region, emphasizing the scientific interest and continued research interest in the area. The transported amount of aerosols to the area of cloud formation is an important aspect of the present study.

\section{Results and discussion}

In the absence of precipitation, fine mode aerosol particles can travel thousands of kilometres from their origin. Furthermore, aerosols in this size range can potentially act as CCN. Andreae et al. (2009) suggest that the typical number size distribution for the aerosols activated as $\mathrm{CCN}$ at $0.3 \%$ supersaturation (a typical median supersaturation in clouds) is in the range of the Aitken to accumulation size mode. Dusek et al. (2006) show that the critical size range for CCN activation is $0.04-0.12 \mu \mathrm{m}$ at a supersaturation between 0.25 and $1.5 \%$. Ramanathan et al. (2001) state that aerosols larger than $0.05 \mu \mathrm{m}$ in diameter can provide the nuclei for most cloud drops. Therefore, as size and chemical composition of the aerosols are important aspects of the particle efficiency to serve as $\mathrm{CCN}$, the fine mode is selected for the investigation 
of the aerosol number density. It should be mentioned that although fine aerosols are generally much more abundant in terms of number concentration compared to the coarse particles, the latter can act as giant CCN $(D>2 \mu \mathrm{m})$ with important effects on precipitation. These effects range from the early development of large drops near the cloud base, the formation of larger graupel particles and possibly acceleration of the precipitation formation in the ice phase, to effects on the radiative properties of the cloud (Feingold et al., 1999; Yin et al., 2000; Teller and Levin, 2006 and references therein). In this work we emphasize the fine mode which includes the first two size sections of the chemistry-transport model, with defined diameter ranges of $0.03-0.1 \mu \mathrm{m}$ (Aitken mode) and 0.1-2.5 $\mu \mathrm{m}$ (accumulation mode).

\subsection{Meteorological conditions}

During August 2005, the quasi-stationary anticyclone over the Azores exhibited high variability with respect to its position and intensity. As indicated in Fig. 1, during the ninth day of the simulation (9 August 2005) the anticyclone was not present in the area, but by the 16 August (and during most of the period) it was well established over the Atlantic Ocean. A major feature of the Azores anticyclone was the N-NE flow along the Western European coastline (from the British Islands, Iberian Peninsula and the NW African coast). This flow carried a relatively cool (for the warm season) air mass over the East Atlantic waters and additionally caused the transport of anthropogenic pollutants from Western Europe and the Mediterranean region to the area of interest (Central Atlantic Ocean). A second important transport pattern was from the Sahara towards the Eastern Atlantic, following the trade wind Easterlies. Through this path, Saharan dust was transported but also anthropogenic pollutants could mix in from Eastern Europe and the Mediterranean through northerly and subsequent easterly transport.

\subsection{Evaluation of the modelled aerosol mass and number concentrations}

Testing of the modelled aerosol mass concentrations is performed using daily measurements from several European sites provided by EMEP and the Airbase public air quality database (European Environment Agency-EEA) for the period 1-30 August 2005 (www.emep.int and http://www.eea. europa.eu/themes/air/airbase). The available data used in this work from EMEP includes $\mathrm{PM}_{10}, \mathrm{PM}_{2.5}$ and $\mathrm{PM}_{10}$ sulphate daily mass concentrations for stations in Spain (ES07-ES16), Italy (IT01, IT04), Turkey (TR01) and Cyprus (CY02). Measurements from eight to ten stations were used, depending on the availability of the data for the specific period. The stations were selected based on whether the sites were influenced by dust and/or sulphate transport and based on their type; all the selected stations are rural background or semirural as the coarse resolution of the model does not allow for
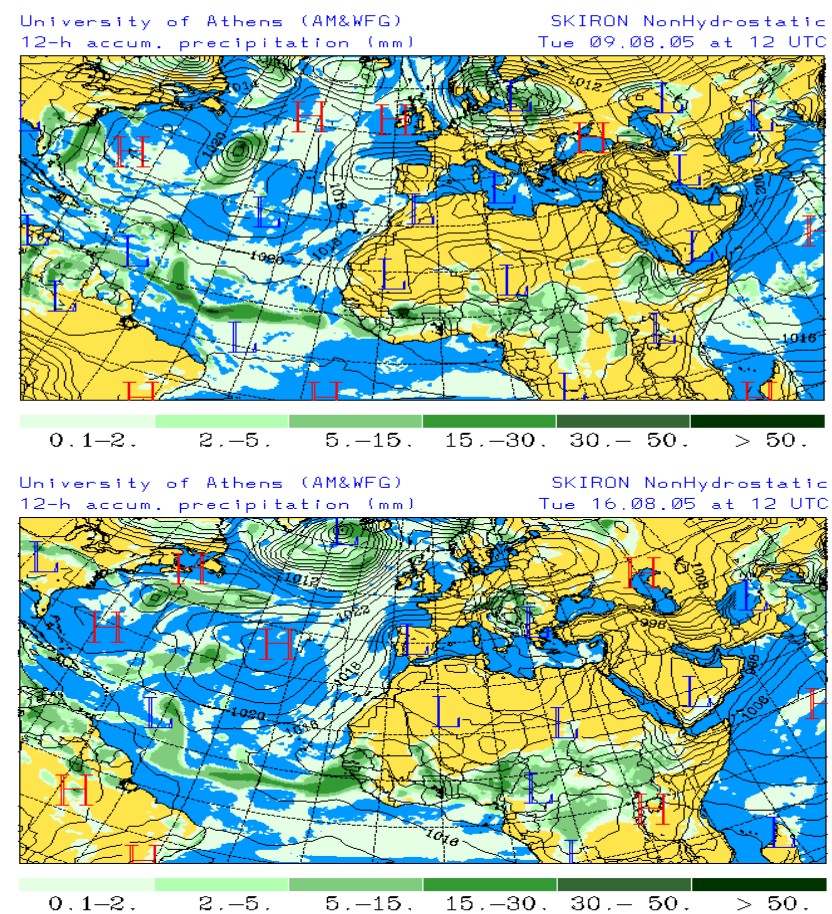

Fig. 1. $12 \mathrm{~h}$ accumulated precipitation and geopotential heights for 9 and 16 August 2005 at 12:00 UTC.

detailed representation of urban or suburban locations. Additional stations providing daily $\mathrm{PM}_{10}$ measurements in the Canary Island (ES0886A), Tenerife (ES1133A) and Madeira (PT0133A and PT0135A) were obtained from EEA (airbase database). Due to their location in the Atlantic Ocean, these stations are important for identifying the dust transport towards the west. Unfortunately, from the 37 available stations in this region, only 11 provided $\mathrm{PM}_{10}$ data for August 2005 and from those only 4 could be used because the coarse resolution of the model included more than one station in a single grid cell. The selection of the four stations was based on their type, preferring the use of background and rural stations when possible. Evaluating the total $\mathrm{PM}_{10}$ mass concentration helps testing the model performance mostly for desert dust as it dominates the larger size section (coarse), while speciated desert dust measurements are rather difficult to acquire. The model performance for the $\mathrm{PM}_{2.5}$ mass concentrations shows in particular its ability to simulate the secondary aerosols (sulphates, nitrates, ammonium) keeping in mind that the model does not account for organic aerosols which can also play an important role in the fine mode aerosol mass concentration. Finally, sulphates within the coarse mode are evaluated as they are an essential part of the current study due to their ability to travel long distances and their hygroscopic nature.

The results of the model evaluation are presented in Table 2 and Fig. 2. The performed statistical analysis includes calculation of the mean predicted, mean observed, root mean 
Table 2a. Comparison of modelled versus measured daily mass concentrations of $\mathrm{PM}_{10}, \mathrm{PM}_{2.5}, \mathrm{PM}_{10}$ Sulfates for the period 2-30 August 2005. Data adopted from the EMEP database (www.emep.int) for stations in Spain (ES07-ES16), Italy (IT01, IT04), Turkey (TR01), and Cyprus (CY02). Additional $\mathrm{PM}_{10}$ data are obtained from the European Environment Agency Airbase public air quality database for stations in Madeira (PT0133A, PT0135A), Tenerife (ES1133A) and the Canary Island (ES0886A).

\begin{tabular}{|c|c|c|c|c|c|c|c|c|c|c|}
\hline & $\begin{array}{l}\text { Mean observed } \\
\left(\mu \mathrm{g} \mathrm{m}^{-3}\right)\end{array}$ & $\begin{array}{l}\text { Mean predicted } \\
\left(\mu \mathrm{g} \mathrm{m}^{-3}\right)\end{array}$ & $\begin{array}{l}\text { RMSE } \\
\left(\mu \mathrm{g} \mathrm{m}^{-3}\right)\end{array}$ & $\begin{array}{l}\mathrm{MB} \\
\left(\mu \mathrm{g} \mathrm{m}^{-3}\right)\end{array}$ & $\begin{array}{l}\text { MAGE } \\
\left(\mu \mathrm{g} \mathrm{m}^{-3}\right)\end{array}$ & $\begin{array}{l}\text { FAC2 } \\
(\%)\end{array}$ & $\begin{array}{l}\text { NME } \\
(\%)\end{array}$ & $\begin{array}{l}\text { NMB } \\
(\%)\end{array}$ & $\begin{array}{l}\mathrm{FB} \\
(\%)\end{array}$ & $\begin{array}{l}\mathrm{FE} \\
(\%)\end{array}$ \\
\hline $\mathrm{PM}_{10}$ (386 data points) & $23.8 \pm 12.4$ & $16.6 \pm 12.4$ & 13.2 & -7.3 & 10.3 & 61.7 & 43.3 & -30.6 & -44.6 & 57.7 \\
\hline $\begin{array}{l}\mathrm{PM}_{10} \text { Sulphates } \\
\text { (274 data points) }\end{array}$ & $2.9 \pm 2.0$ & $3.5 \pm 1.6$ & 1.5 & 0.6 & 1.2 & 81.8 & 40.8 & 22.2 & 26.8 & 40.1 \\
\hline
\end{tabular}

Notes: RMSE=Root mean square error, MB=mean bias, MAGE=mean absolute gross error, FAC2=percentage within a factor of 2, $\mathrm{NME}=$ normalized mean error, $\mathrm{NMB}=$ normalized mean bias, $\mathrm{FB}=$ fractional bias, $\mathrm{FE}=$ fractional error.

Table 2b. Comparison of modelled versus measured daily aerosol number concentrations for the period 2-30 August 2005. Data adopted from the database maintained by the Norwegian Institute for Air Research (NILU-EBAS database) and through personal communication with the data providers.

\begin{tabular}{lllllllllll}
\hline Stations & $\begin{array}{l}\text { Mean observed } \\
\left(\mathrm{cm}^{-3}\right)\end{array}$ & $\begin{array}{l}\text { Mean predicted } \\
\left(\mathrm{cm}^{-3}\right)\end{array}$ & $\begin{array}{l}\text { RMSE } \\
\left(\mathrm{cm}^{-3}\right)\end{array}$ & $\begin{array}{l}\text { MB } \\
\left(\mathrm{cm}^{-3}\right)\end{array}$ & $\begin{array}{l}\text { MAGE } \\
\left(\mathrm{cm}^{-3}\right)\end{array}$ & $\begin{array}{l}\text { FAC2 } \\
(\%)\end{array}$ & $\begin{array}{l}\text { NME } \\
(\%)\end{array}$ & $\begin{array}{l}\text { NMB } \\
(\%)\end{array}$ & $\begin{array}{l}\text { FB } \\
(\%)\end{array}$ & $\begin{array}{l}\text { FE } \\
(\%)\end{array}$ \\
\hline $\begin{array}{l}\text { FR030 and CH01 } \\
\text { (677 data points) }\end{array}$ & $1175 \pm 735$ & $1402 \pm 761$ & 722 & 226 & 560 & 72 & 47.6 & 19.2 & 21.4 & 48.2 \\
$\begin{array}{l}\text { Melpitz DE44 } \\
\begin{array}{l}\text { (348 data points) } \\
\text { Zugspitze }\end{array}\end{array}$ & $1979 \pm 1138$ & $1898 \pm 1165$ & 1130 & -80 & 872 & 66.7 & 43.8 & -4.1 & -7.9 & 50.7 \\
(326 data points) & $2020 \pm 1167$ & $1899 \pm 1366$ & 1226 & -122 & 923 & 71.8 & 45.5 & -6 & -9.7 & 47 \\
\hline
\end{tabular}

square error (RMSE), mean bias (MB), mean absolute gross error (MAGE), normalized mean error (NME), normalized mean bias (NMB), fractional error (FE), fractional bias (FB) and the fraction of data within a factor of 2 (FAC2) for a series of model-observation pairs (Table 2). For the comparison with the measurements, values of the species mass concentrations at the first model layer were used $(0-50 \mathrm{~m}$ above ground). The definition of each statistical metric is provided in the Appendix (EPA, 2007). The above metrics followed by the scatter diagrams in Fig. 2 provide a general overview of the model performance for the particulate matter mass concentrations. The $\mathrm{PM}_{10}$ model mass concentration is approximated by summing the modelled mass concentrations of desert dust, sulphates and nitrates (anthropogenic and formed on dust), ammonium, sodium and chloride aerosols of all size sections. $\mathrm{PM}_{2.5}$ model mass concentration is approximated by summing the mentioned species of the first two size sections (Table 1).

$\mathrm{PM}_{10}$ and $\mathrm{PM}_{2.5}$ are generally underestimated, as indicated by the negative mean, fractional and normalized mean biases (MB, FB and NMB) which are metrics sensitive to systematic errors $\left(\mathrm{MB}=-7.3 \mu \mathrm{g} / \mathrm{m}^{3}, \mathrm{NMB}=-30.6 \%\right.$ for $\mathrm{PM}_{10}$ and $\mathrm{MB}=-3.8 \mu \mathrm{g} / \mathrm{m}^{3}, \mathrm{NMB}=-35.67 \%$ for $\mathrm{PM}_{2.5}$ ). The underestimation of the measured mass concentrations is expected, since the model simulation did not include organic aerosols and because the coarse horizontal resolution of the simulation hinders the validation effort. This is confirmed by the scatter diagrams in Fig. 2a-b, where the correlation coefficients are 0.47 and 0.60 for $\mathrm{PM}_{2.5}$ and $\mathrm{PM}_{10}$, respectively. The linear regression of the $\mathrm{PM}_{10}$ scatter diagram shows a relatively good model performance for the coarse aerosol, possibly because the organic aerosol mass is only minor. The mean absolute error (MAGE) is $10.3 \mu \mathrm{g} / \mathrm{m}^{3}$ for $\mathrm{PM}_{10}$ and $5.02 \mu \mathrm{g} / \mathrm{m}^{3}$ for $\mathrm{PM}_{2.5}$. The normalized mean error (NME) is $43.3 \%$ for $\mathrm{PM}_{10}$ and $47.09 \%$ for $\mathrm{PM}_{2.5}$. These metrics show the overall discrepancy between predictions and observations and the percentages below $50 \%$ are considered to represent an acceptable performance. The fractional biases and errors for both species are below $\pm 60 \%$ ( $-67 \%$ and $+67 \%$ are considered biased within a factor of 2) and this result confirms the good model performance. The model predictions that are within 2 and 0.5 times the observations (FAC2) are 61.7\% for $\mathrm{PM}_{10}$ and $58.29 \%$ for $\mathrm{PM}_{2.5}$. This statistical metric is considered more robust than the traditional correlation coefficient, since it is not sensitive to outlier data pairs (high or low) as the correlation coefficient. Nevertheless, both metrics are calculated and stated in Fig. 2 and Table 2. Time series of the modelled and measured $\mathrm{PM}_{10}$ and $\mathrm{PM}_{2.5}$ for each station are provided in the supplement that accompanies the article. 
The statistical analysis for the coarse sulphate aerosols shows that the model also performs reasonably well for the sulphates. The mean observed and modelled values are in good agreement (Table 2), the RMSE $\left(1.54 \mu \mathrm{g} / \mathrm{m}^{3}\right)$, MAGE $\left(1.18 \mu \mathrm{g} / \mathrm{m}^{3}\right)$ and MB $\left(0.64 \mu \mathrm{g} / \mathrm{m}^{3}\right)$ are quite low, as well as all the other statistical metrics. $81.75 \%$ of the modelled values are within 2 and 0.5 times the observations (FAC2) and the linear regression of the modelled versus observed values (Fig. 2c) shows a good performance with a correlation coefficient of 0.71 . The metrics discussed above provide reasonable confidence in the model performance.

When addressing issues of transport and transformation of pollutants, it is common to use the mass concentration of species or the integrated mass load or both. When the aim is to address the complex interactions between aerosols and clouds, it is preferable to use the number concentration. The conventional use of mass does not account for the chemical and physical characteristics of the aerosols which are important in assessing their effects on clouds and/or precipitation (Andreae et al., 2009). The number distribution for each size section is calculated with the use of the modelled mass concentration fields, the mass of a single particle (assumed to be spherical) and the geometric mean diameter of each size section $\left(d_{g}=\sqrt{d_{i} \times d_{i+1}}\right.$, where $i$ is the lower size cut point of each section bin).

Consequently, in addition to the aerosol mass concentrations, a comparison has been performed between the calculated aerosol number concentrations and measurements publicly available for August 2005 (Fig. 3). The number of stations providing such data for 2005 is limited and we acquired hourly data from four stations in France, Switzerland and Germany from the database maintained by the Norwegian Institute for Air Research (NILU-EBAS database) and through personal communication with the data providers. Since the model produced $2 \mathrm{~h}$ average output fields, the comparison between modelled and observed values was realized on a $2 \mathrm{~h}$ average basis. The station in France is Puy de Dome (FR0030R, 45.77 N-2.97 E, $1465 \mathrm{~m}$ a.s.l.) and the one in Switzerland is Jungfraujoch (CH0001G, $46.55 \mathrm{~N}-7.985 \mathrm{E}$, $3580 \mathrm{~m}$ a.s.1.). They both used a condensation particle counter instrument (CPC TSI 3010) for the aerosol number distribution, covering aerosol sizes larger than $0.01 \mu \mathrm{m}$ for FR0030 and in the range $0.005-10 \mu \mathrm{m}$ for CH0001 (diameter). The comparison with the total number concentration calculated from the modeled mass gave a reasonable agreement with a correlation coefficient of approximately 0.6 (within a total number of 677 pair values) as shown in Fig. 3a. The modeled aerosols used for calculating the total number concentration are dust (density $=2.6 \mathrm{~g} / \mathrm{cm}^{3}$ ), sodium $\left(\right.$ density $=2.0 \mathrm{~g} / \mathrm{cm}^{3}$ ), nitrate and nitrate on dust (density $=1.5 \mathrm{~g} / \mathrm{cm}^{3}$ ), sulfate and sulfate on dust $\left(\right.$ density $\left.=1.5 \mathrm{~g} / \mathrm{cm}^{3}\right)$, and ammonium (density $\left.=1.5 \mathrm{~g} / \mathrm{cm}^{3}\right)$. The statistical analysis of the aerosol number concentration appears in Table $2 b$, using the same metrics as for the $\mathrm{PM}_{10}, \mathrm{PM}_{2.5}$ comparison. Average and standard deviation

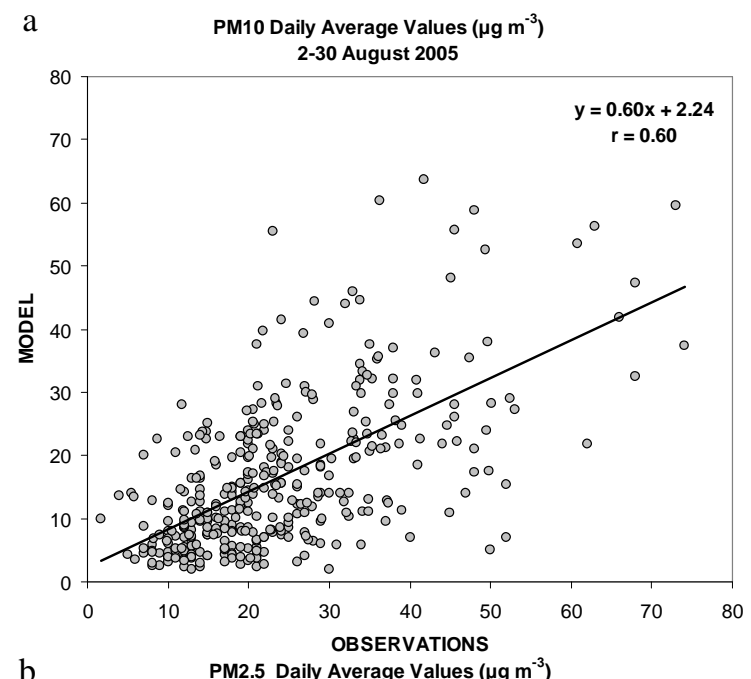

b
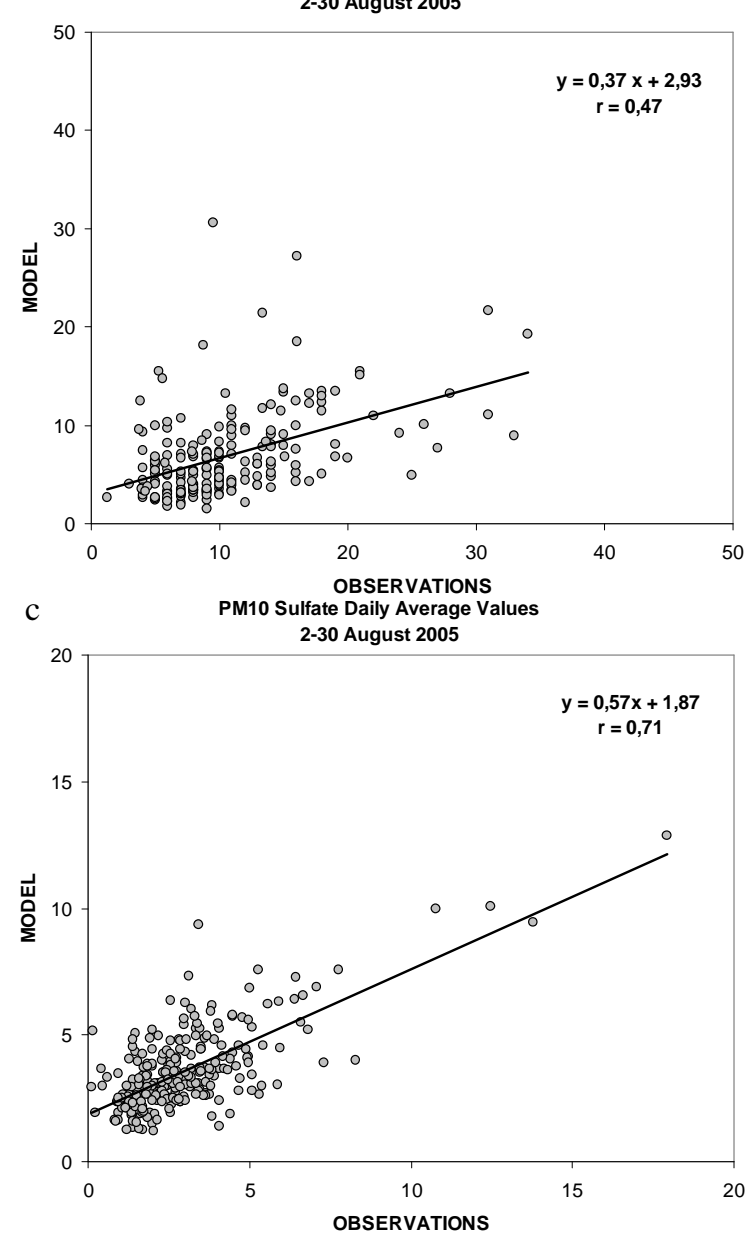

Fig. 2. Comparison between modelled and measured mass concentrations of (a) $\mathrm{PM}_{10}$, (b) $\mathrm{PM}_{2.5}$ and (c) $\mathrm{PM}_{10}$ Sulphates for the period 2-30 August 2005. The stations used are adopted from the EMEP and EEA (Airbase) databases. In each panel the linear regression and the correlation coefficient $(r)$ are shown. 

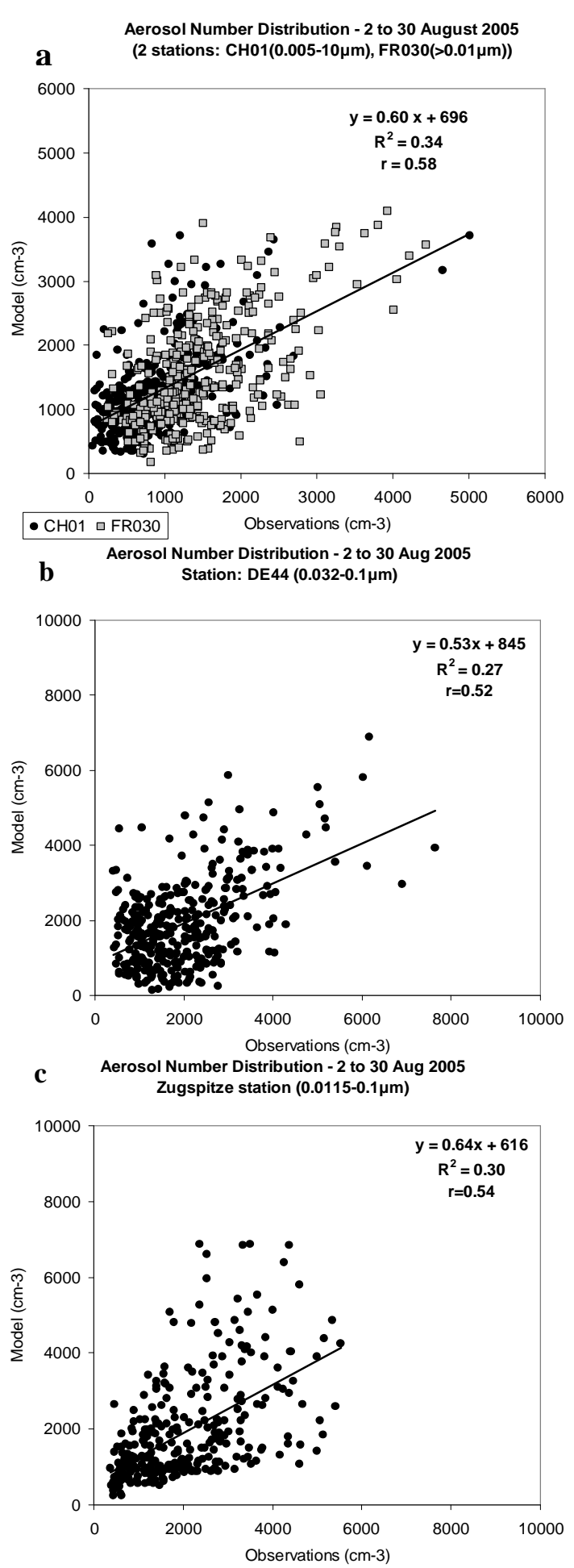

Fig. 3. Comparison between modelled and measured number concentrations $\left(\mathrm{cm}^{-3}\right)$ for four stations during the period 2-30 August 2005: (a) Jungfraujoch station (CH01, $3580 \mathrm{~m}$ a.s.l., black dots) and Puy de Dome (FR030, 1465 ma.s.l., grey squares) station. The linear regression line refers to data from both stations, (b) Melpitz (DE44, $87 \mathrm{~m}$ a.s.l) station and (d) Zugspitze station (2650 m a.s.1.). values were $1175 \pm 735 \mathrm{~cm}^{-3}$ and $1402 \pm 761 \mathrm{~cm}^{-3}$ for measurements and model values respectively. The RMSE $\left(722 \mathrm{~cm}^{-3}\right), \operatorname{MB}\left(226 \mathrm{~cm}^{-3}\right)$, and $\operatorname{MAGE}\left(560 \mathrm{~cm}^{-3}\right)$ are not very low and this is explained by the high values representing this field as the 90th percentile was $2123 \mathrm{~cm}^{-3}$ for the observations and $2512 \mathrm{~cm}^{-3}$ for the model number concentrations and the 10th percentile was $365 \mathrm{~cm}^{-3}$ for the observations and $609 \mathrm{~cm}^{-3}$ for he modeled values. Low values can be seen in the normalized and fractional biases and errors, which strengthen the reliability of the modeled values. For the data pairs of the two stations the statistical analysis has shown that $72 \%$ of the modeled data is within 2 and 0.5 times the observations (FAC2).

The small overestimation of the measured average number concentration originates mostly from the comparison with the Jungfraujoch station (CH0001G). For some days in August the model overestimates the number concentration measured in this station, probably due to overestimation of the fine particulate sulfate (the largest portion of the number concentration comes from the smallest size section). Jungfraujoch is an alpine research station located at $3580 \mathrm{~m}$ above sea level, surrounded by highly industrialized regions at lower altitudes. Cozic et al. (2008) analyzed time series of measurements in Jungfraujoch station and have shown that the $\mathrm{PM}_{1}$ mode mass concentration is mainly composed of organic matter and sulphates with a smaller contribution from nitrates, ammonium and black carbon for August 2005. The available number concentration measurements span a diameter range of $0.005-10 \mu \mathrm{m}$, which does not enable evaluating the model results based on the model's diameter size bins. As organic aerosols are not part of the current simulation, it was expected that the comparison with the measurements would exhibit deviations from a 1:1 relationship, especially near the species source locations. Overall, the number concentration calculated from the model for the first two stations which are located in the heart of anthropogenic emission sources, can be considered reasonable without large discrepancies.

The other two stations used for the comparison of the aerosol number concentration are located in Germany. The aerosol measurements from the Melpitz station (DE44, $51.53 \mathrm{~N}-12.90 \mathrm{E}, 87 \mathrm{~m}$ a.s.1.) are obtained with the use of a twin differential mobility particle sizer (TDMPS) (Engler et al., 2007; Putaud et al., 2004). A Single Scanning Mobility Particle Sizer (SMPS) was used for the measurements in the Zugspitze station (47.42 N-10.98 E, $2650 \mathrm{~m}$ a.s.1.) (W. Birmili et al., 2009a, b and personal communication, 2009). These two techniques are similar but the size cut-offs of the aerosols differ which enables different comparison plots and metrics for these stations (Fig. $3 b$ and c). The fine fraction of the aerosol number distribution was available $(0.028-$ $0.86 \mu \mathrm{m})$ in 40 size bins in the Melpitz station. To be in accordance with the model results, we added the size bins in the range $0.032-0.1 \mu \mathrm{m}$ ( 8 bins) and compared with the first size section of the modeled number concentration $(0.03-0.1 \mu \mathrm{m}$, Aitken mode). As shown in Fig. 3b, the calculated number 
distribution correlates reasonably well with the measured values $(r=0.52)$. The average and standard deviation values for measured and modeled values are $1979 \pm 1138 \mathrm{~cm}^{-3}$ and $1898 \pm 1165 \mathrm{~cm}^{-3}$ respectively (total number of 348 pair values). The RMSE $\left(1130 \mathrm{~cm}^{-3}\right), \operatorname{MB}\left(-80 \mathrm{~cm}^{-3}\right)$, and MAGE $\left(872 \mathrm{~cm}^{-3}\right)$ are higher than the previous stations. The 90th percentile was $3337 \mathrm{~cm}^{-3}$ for the observations and $3464 \mathrm{~cm}^{-3}$ for the model number concentrations and the $10 \mathrm{th}$ percentile was $794 \mathrm{~cm}^{-3}$ for the observations and $607 \mathrm{~cm}^{-3}$ for he modeled values. Low values can be seen in the normalized and fractional biases and errors. $66.7 \%$ of the modeled values are within 0.5 and 2 times the observations $(88 \%$ of the modeled values are lower than 2 times the observed values). The Melpitz sampling site in eastern Germany is surrounded by populated areas with anthropogenic aerosol sources (Engler et al., 2007).

For the alpine station on the Zugspitze the comparison is also considered reasonable and the modeled number concentrations agree quite well with the observations (Fig. 3c). The site is located at $2650 \mathrm{ma}$ a.s.l. and the aerosol number concentration is given for the diameter size range of $0.0115-0.585 \mu \mathrm{m}$ in 40 size bins. The first size section of the model is used $(0.03-0.1 \mu \mathrm{m}$, Aitken mode) against the summation of the first 23 size sections of the measurements $(0.0115-0.105 \mu \mathrm{m})$. The average and standard deviation values for measured and modeled values are $2020 \pm 1167 \mathrm{~cm}^{-3}$ and $1899 \pm 1366 \mathrm{~cm}^{-3}$ respectively (total number of 326 pair values). The RMSE $\left(1226 \mathrm{~cm}^{-3}\right), \mathrm{MB}\left(-122 \mathrm{~cm}^{-3}\right)$, and MAGE $\left(923 \mathrm{~cm}^{-3}\right)$ are higher than the previous stations and this is evident also from the scatter diagram in Fig. 3c. The 90th percentile was $3651 \mathrm{~cm}^{-3}$ for the observations and $3918 \mathrm{~cm}^{-3}$ for the model number concentrations and the 10 th percentile was $661 \mathrm{~cm}^{-3}$ for the observations and $690 \mathrm{~cm}^{-3}$ for he modeled values. The normalized and fractional biases and errors are quite low as for the previous stations. $71.8 \%$ of the modeled values are within 0.5 and 2 times the observations $(90.8 \%$ of the modeled values are lower than 2 times the observed values). For all the stations used in the evaluation, the results from the comparison between calculated and measured aerosol number concentrations show an acceptable agreement. This result should be evaluated keeping in mind that the calculated aerosol number concentration from the modeled mass concentration is an assumption and it can not produce values as detailed and accurate as a lognormal size distribution. Also, an important issue for the underestimation of the number concentration is the exclusion of the organic aerosols (primary and secondary) which are part of the total aerosol number concentration in the observations. Nevertheless, since it seems reasonable to assume an internal mixture of the aerosol, the neglect of organics in the model is likely to affect more strongly the mass than the number concentration. Overall, the calculated aerosol number concentration compared to the observed values gives confidence in the model's ability to reproduce the number concentration. This is important for the main goal of this work which concerns the characterization of the aerosols over the Central Atlantic Ocean in terms of number and size distribution and chemical composition.

Continuing with the ability of the model to simulate the columnar aerosol mass load, a qualitative comparison is made between predicted values and those inferred from observations by the Moderate Resolution Imaging Spectroradiometer (MODIS) aboard the National Aeronautics and Space Administration's (NASA) Aqua and Terra satellite platforms. Tropospheric columnar aerosol mass loads are obtained from the MODIS Collection 5 Level- 3 global $1 \times 1$ degree dataset. They are based on the weighted combination of retrieved fine and coarse mode aerosol optical depths and the mass concentration coefficients of the aerosol models used in the Collection 5 retrieval algorithm (Remer et al., 2006). Whereas the aerosol optical depths are considered to be "validated", the aerosol mass loads are derived products since they do not represent solutions to the retrieval inversion procedure. Hence, their usefulness for a direct pixel-to-gridbox comparison is rather limited, but for spatial structures and relative magnitudes they do provide a useful means for assessing the model performance.

In Figs. 4 and 5 (left column panels) the aerosol mass loads represent a composite of retrievals based on both the land and ocean algorithms. Gaps in the data are primarily caused by clouds or the inability of the algorithm to perform retrievals over bright surfaces. To maximize the number of observations for a given day, data from both Terra during the morning and Aqua in the afternoon are used. Where valid retrievals are available for the same pixel for the two different observational times, the value provided represents an average of the two retrievals. The satellite data are available for the whole period of August 2005; however specific days are selected for discussion in August 2005: 14th-16th in Fig. 4; 27th and 28th in Fig. 5. It should be noted that the aerosol optical depth is not a standard model output field; hence it could not be used in the evaluation procedure.

The modelled daily $\mathrm{PM}_{10}$ values are determined by the sum of sulphates, nitrates, dust, sodium chloride, and the chemically aged and mixed aerosols (sulphates and nitrates on dust). The modelled mass load represents the vertical integration of the simulated atmospheric column from $0-10 \mathrm{~km}$ whereas the satellites cover the entire atmospheric column. As can be seen from Figs. 4 and 5 the model calculated aerosol plumes over the Central Atlantic region follow similar spatial patterns compared to the satellite-based data. In particular, the model agrees very well with the observations for the aerosol plume structure as it expands out into the Atlantic. The weaker match for the 14th along the coast and the spatial dislocation on the 28th may be related to temporal mismatches since the satellite observations occur in the middle of the day and the model output represents daily averages. Also, there is a strong maximum in the satellite data on 15 and 16 August, close to the Canary Islands (Fig. 4), which is underestimated by the model. The maximum in the model is 


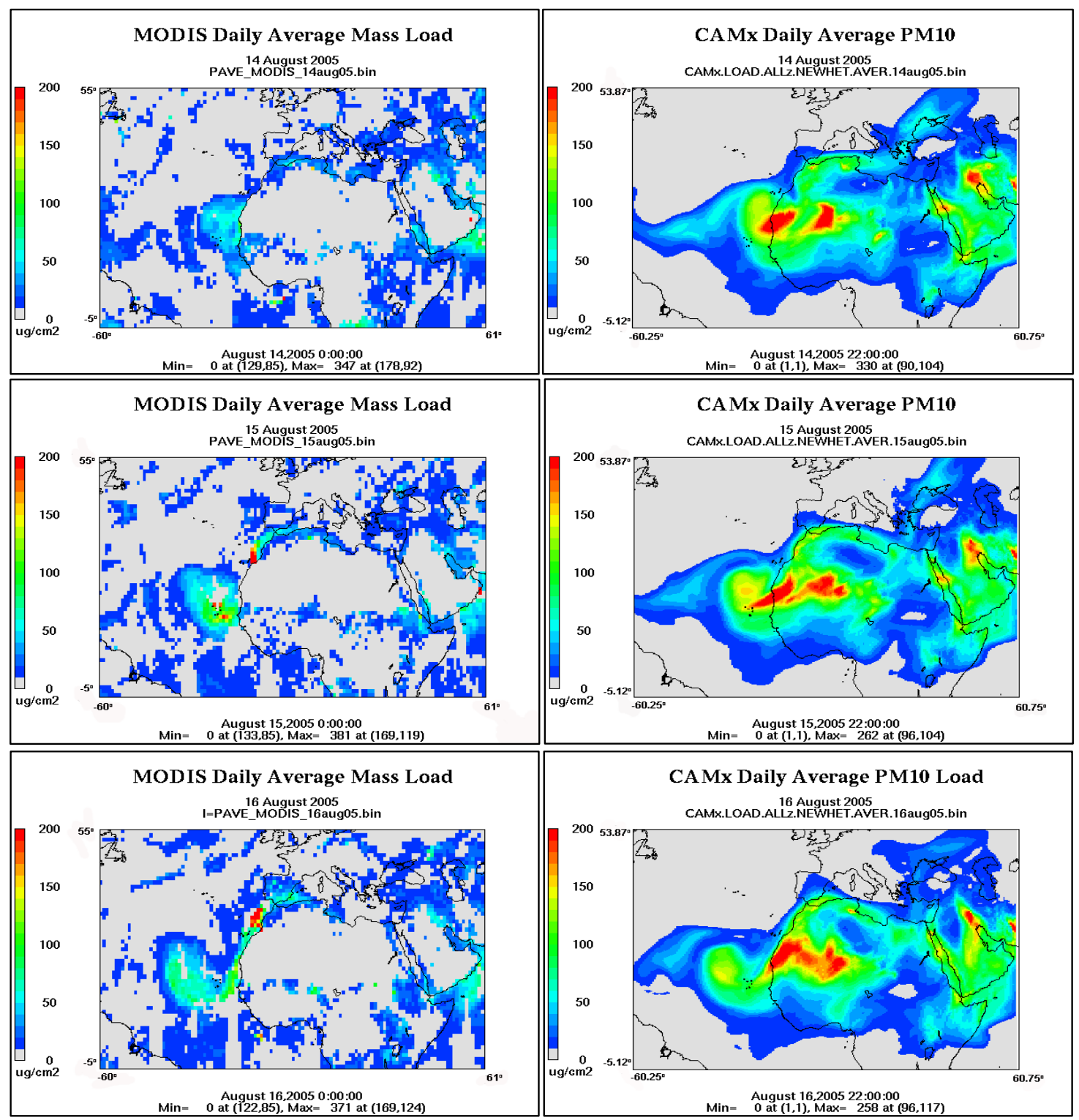

Fig. 4. Daily average mass load of aerosols from MODIS satellite (left) and from the model simulation (right) ( $\left.\mu \mathrm{g} / \mathrm{cm}^{2}\right)$ for $14-16$ August 2005. The grey areas in the satellite images are areas with no satellite data.

inland and rather close to the coast while the satellite shows the maximum above the sea. There may be two reasons for this difference; one is spatial dislocation of the simulated aerosol mass load and the second could be the underestimation of aerosols like dust and sulphates (together with the absent organics and DMS fluxes from the sea). While the peak values are of the same magnitude, the model generally produces higher mass concentrations than those inferred from the satellite observations (as for the $20 \mathrm{~h}$ of August in Fig. 5). This result is not unexpected since the satellite based estimates rely on a mass concentration coefficient that is set to a fixed value for the aerosol models used in the retrievals and e.g. do not vary with humidity. Overall, this comparison to- gether with the previous statistical analysis gives reasonable confidence of the ability of the modelling system to simulate the production, transformation and transport of aerosols.

\subsection{Case selection for the typical aerosol number concentrations}

For a few selected days of August 2005 we perform a detailed analysis based on the triple criterion that in the storm genesis region (the area of the Central Atlantic Ocean where cloud formation and convective activity are initiated), clouds, aerosols and small amounts of rain coexist. These days are identified by examining the integrated aerosol column mass 

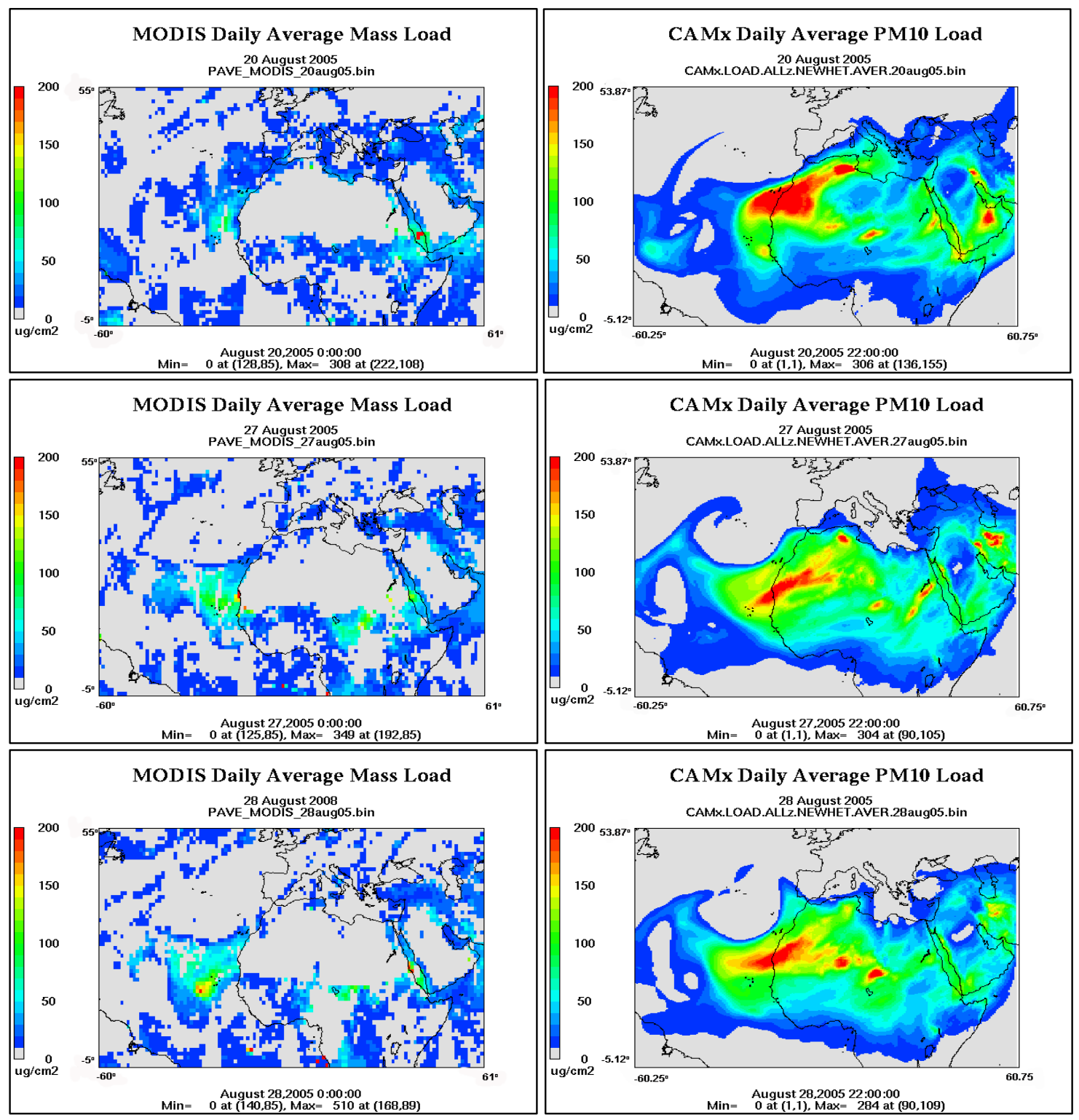

Fig. 5. As in Fig. 3, for 20, 27 and 28 August 2005.

load and the cloud water content in the model vertical layers. Cloud water content is used instead of the cloud cover, since it is explicitly calculated by the atmospheric model SKIRON/Dust. Cloud cover in the CAMx model is diagnosed during the simulation. Sub-grid scale clouds are not represented in the model. Clouds are either occupying the entire cell or are absent, depending on the condensed cloud water content (CWC) values. When the CWC is above the threshold of $0.05 \mathrm{~g} / \mathrm{m}^{3}$ the grid cell is designated as cloudy. As indicated in Seinfeld and Pandis (2006) the liquid water content of a cloud varies approximately from 0.05 to $3 \mathrm{~g} / \mathrm{m}^{3}$, with the most frequent observed values in the range $0.1-0.3 \mathrm{~g} / \mathrm{m}^{3}$. In some cases, such as in deep convective clouds over the ocean it can exceed $3 \mathrm{~g} / \mathrm{cm}^{3}$. Also, the $\mathrm{CWC}$ has a characteristic range of values for different cloud types. Hence, the CWC is selected as the marker of cloud formation in the region under investigation.

Two days were selected for the extended discussion about the atmospheric conditions during the second half of August 2005, the 16th and 27th. On the 16 and the $27 \mathrm{Au}-$ gust 2005, cloud formation was evident, beginning with low clouds in the area of interest, and expanding in the vertical direction as they were travelling west towards the Central Atlantic Ocean. Concentrating on the CWC and the aerosol mass load in two vertical layers of the model $(300-450 \mathrm{~m}$ and $450-600 \mathrm{~m}$ ), two interesting areas were found, one for 


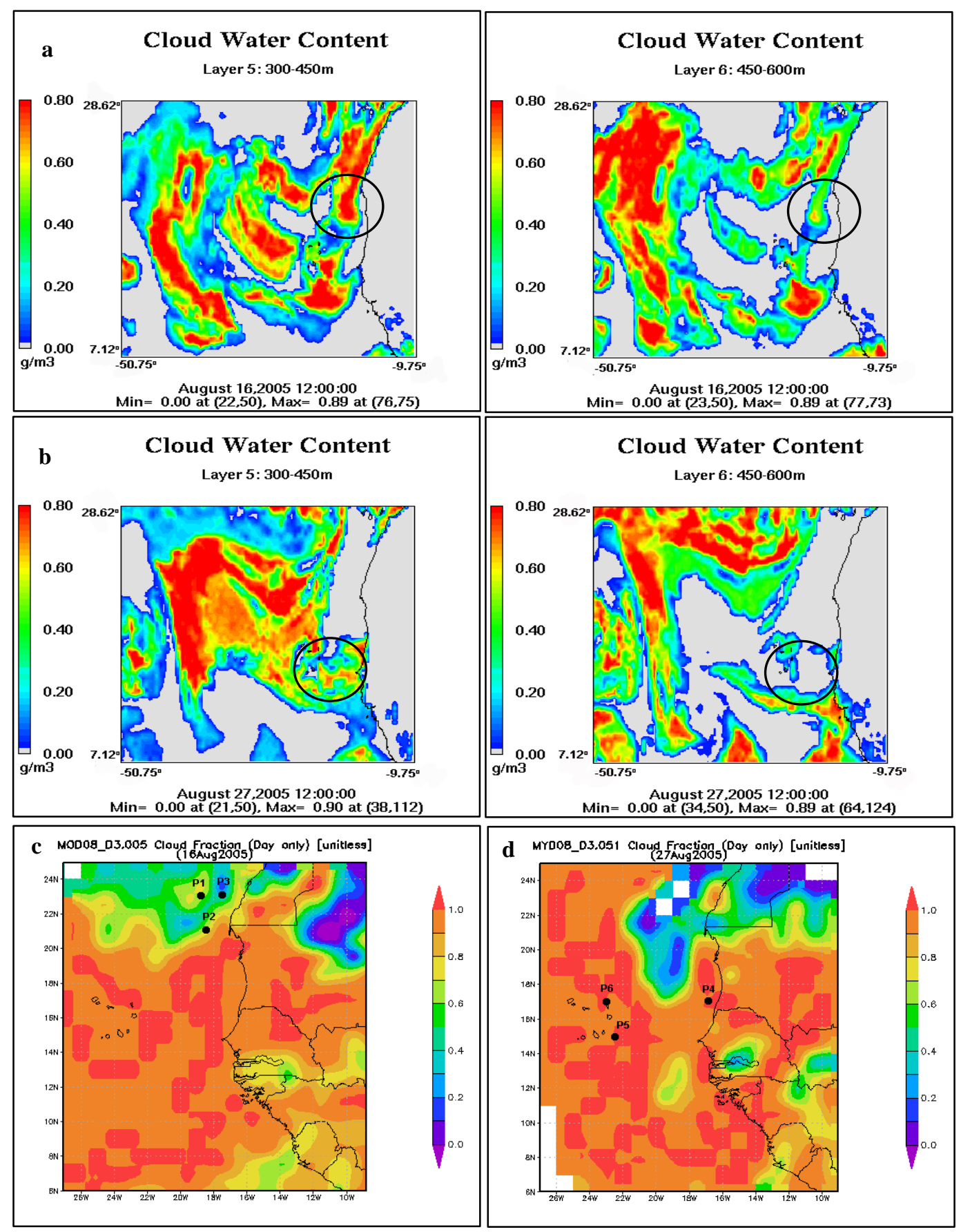

Fig. 6. Hourly condensed cloud water content (CWC) during (a) 16 and (b) 27 August $2005\left(\mathrm{~g} / \mathrm{m}^{3}\right)$ at 12:00 UTC. The left to right panels indicate two vertical layers, 300-450 m and 450-600 m respectively. The domain shown is the one indicated with a rectangular box in Fig. 8 . (c) Daily cloud fraction from MODIS Terra v.5 for 16 August 2005. The black dots denote the approximate position of the locations P1 to P3. (d) Daily cloud fraction from MODIS Aqua v5.1 for 27 August 2005. The black dots denote the approximate position of the locations P4 to P6.

each day (Fig. 6a and b). The CWC reached 0.8 to $0.9 \mathrm{~g} / \mathrm{m}^{3}$ in these areas (denoted with a black circle in Fig. 6) and an aerosol plume enters the area of interest (from the daily average mass load of the species under investigation in Fig. 7).
The region illustrated in Figs. 6 and 7 is a zoomed area of the simulation domain, indicated with the rectangular box in Fig. 8. The daily cloud fraction (during the day) from MODIS satellite is also shown in Fig. $6 \mathrm{c}$ and d, denoting the 


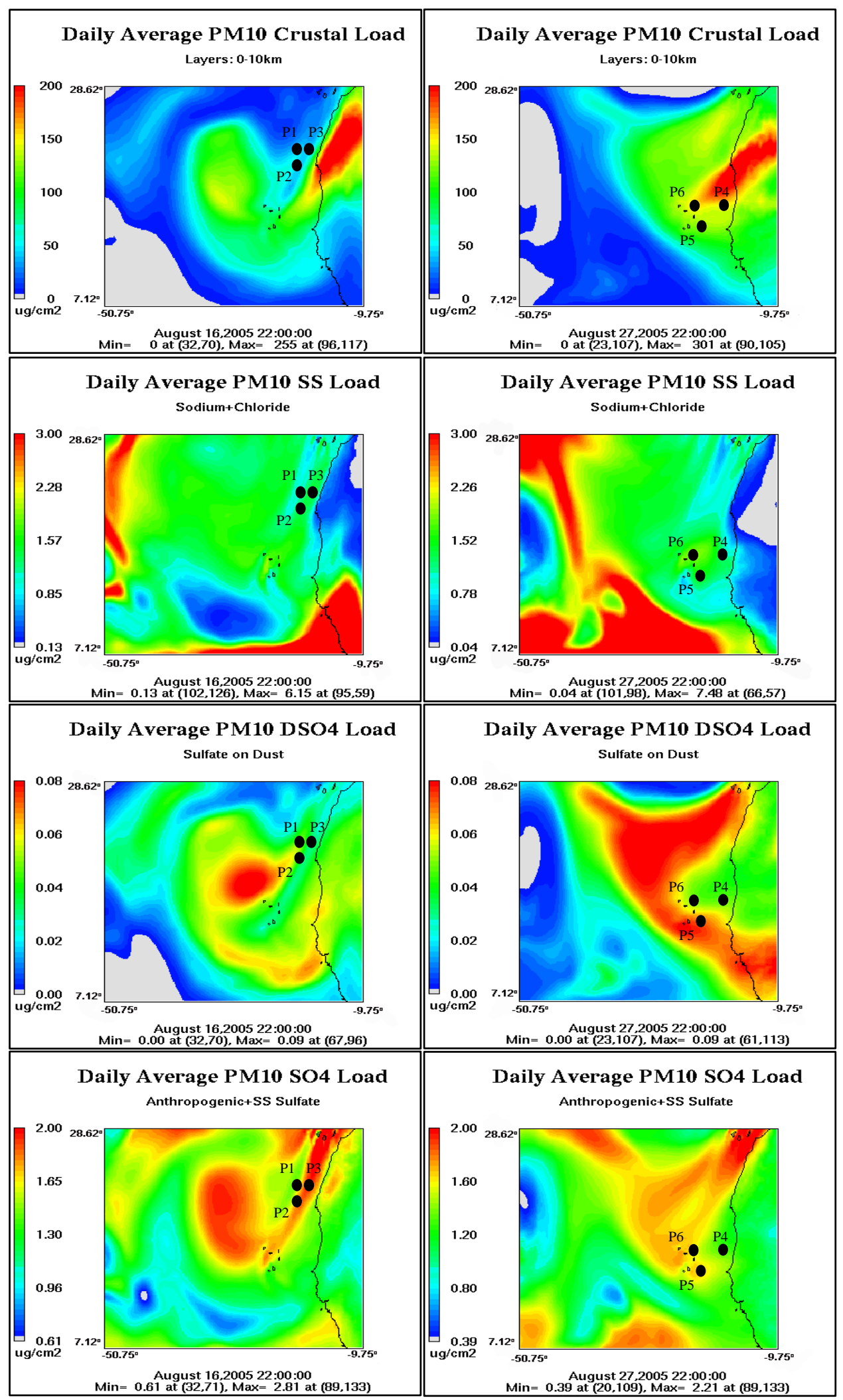

Fig. 7. Integrated column mass load $\left(\mu \mathrm{g} / \mathrm{cm}^{2}\right)$ for desert dust (crustal), sea salt aerosol, sulphate on dust and anthropogenic sulphate particles. The left column is for 16 August 2005 and the right for 27 August 2005. 


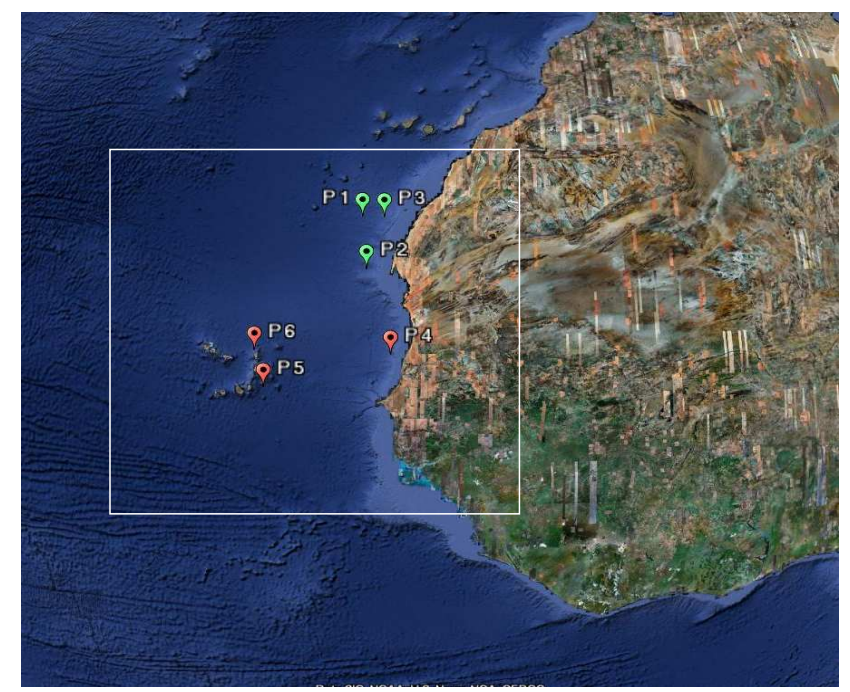

Fig. 8. Location of the points used for the vertical profile of the aerosol number distribution (the green points are for $16 \mathrm{Au}-$ gust 2005 and the red points for 27 August 2005) (image from Google Earth). The rectangular box denotes the area under investigation for the chemical composition and vertical number distribution of the aerosols.

presence of cloud formations in the respective locations discussed previously. The locations P1 to P6, shown in these plots, are the chosen locations for the analysis of the number concentration vertical profiles, which will be analyzed in the next section.

The maximum daily average mass loads for each aerosol type in the zoomed area of Fig. 7 are quite similar for the two days (16 and 27 August). The mass load refers to the integrated aerosol column mass load (an integral over height). The desert dust maximum is $255 \mu \mathrm{g} / \mathrm{cm}^{2}$ on the 16 th and $301 \mu \mathrm{g} / \mathrm{cm}^{2}$ on the 27 August. The sea salt maximum is $6.2 \mu \mathrm{g} / \mathrm{cm}^{2}$ and $7.5 \mu \mathrm{g} / \mathrm{cm}^{2}$ for the two days, respectively. The sulphate on dust maximum mass load is $0.09 \mu \mathrm{g} / \mathrm{cm}^{2}$ on both days and anthropogenic sulphate is $2.8 \mu \mathrm{g} / \mathrm{cm}^{2}$ and $2.2 \mu \mathrm{g} / \mathrm{cm}^{2}$, respectively. Large differences occur among the different aerosol types, with desert dust having the largest daily average mass load as mentioned above. This result, in conjunction with the total daily values in Figs. 4 and 5, shows that the maximum values are related to desert dust and the rest of the species contribute with smaller mass loads. During all simulated days, daily mass loads of desert dust reach $200-300 \mu \mathrm{g} / \mathrm{cm}^{2}$ along the West African coastline. Over the Atlantic Ocean the maximum daily sodium chloride mass load is approximately $9 \mu \mathrm{g} / \mathrm{cm}^{2}$. For the daily anthropogenic aerosols in this region (sulphates and nitrates) the mass load reaches $8-9 \mu \mathrm{g} / \mathrm{cm}^{2}$ and for the chemically aged and mixed dust aerosols $3-4 \mu \mathrm{g} / \mathrm{cm}^{2}$ is computed. The contributions by the various aerosol types appear rather different when we consider number distribution, as analyzed below.

\subsection{Aerosol vertical profiles - aerosol number distribution}

The vertical profiles are shown for the lowest $5 \mathrm{~km}$ of the atmosphere, as significant aerosol transport towards the cloud layers takes place. During the simulation days, no deep convective activity was evident in the areas of high aerosol concentrations. Our study mainly associates the aerosols with stratus, stratocumulus and cumulus cloud types, according to the CWC vertical profiles. As expected, the aerosols in the smaller size section - Aitken mode $(0.03-0.1 \mu \mathrm{m})$ - exhibit higher number concentrations than the ones in the range of 0.1-2.5 $\mu \mathrm{m}$ (accumulation mode). To examine the time evolution of the aerosol/cloud coexistence, vertical profiles were derived every $6 \mathrm{~h}$ for all the selected locations in the domain of interest. These locations are shown in Fig. 8 with the green points indicating profiles for 16 August (P1-P3) and the red ones showing locations for 27 August (P4-P6). The locations were selected using the criterion of simultaneous presence of cloud, all of the studied aerosol types and the absence of rain. The main interest was that all the different aerosol types enter the region of cloud formation, and we selected areas where aerosol/cloud interaction processes commence. For each location and time two vertical distributions are presented; one for the Aitken and one for the accumulation mode (Figs. 914). The numerical scale in the Figs. 9-14 for each mode is different because the values can differ up to 1 or 2 orders of magnitude for the same species.

At the first location $\mathrm{P} 1$ (lat $23.5^{\circ} \mathrm{N}$, lon $18.5^{\circ} \mathrm{W}$ ) the vertical profile for the Aitken mode (Fig. 9, left panels) shows a clear stratification above the cloud top mostly for sulphates, whereas the other species exhibit a much smoother vertical distribution. Dust (CRST_1), sodium containing sea salt (NA_1), anthropogenic sulphates (PSO4_1) and sulphate on dust (DSO4_1) have maximum number concentrations of $188,9.4,1260$ and 30 particles $/ \mathrm{cm}^{3}$, respectively. The accumulation mode does not indicate significantly enhanced accumulation mode aerosols in the vicinity of the cloud formation (Fig. 9, right panels). Desert dust (CRST_2), sodium dominated sea salt (NA_2), sulphate (PSO4_2) and sulphate on dust (DSO4_2), reach 26, 2.5, 45 and 0.6 particles $/ \mathrm{cm}^{3}$ respectively. For both modes, it appears that the aerosols are mostly affecting the cloud layers with high number concentrations from above. This result is in agreement with some observations in other parts of the world that found anthropogenic particles also above the clouds (Levin et al., 2005). A most interesting vertical distribution is of the anthropogenic sulphates (PSO4_1), being stratified above the cloud top, having a maximum of 1260 particles $/ \mathrm{cm}^{3}$ at $1.3 \mathrm{~km}$ altitude.

The second location P2 (lat $\left.=21.0^{\circ} \mathrm{N}, \mathrm{lon}=18.2^{\circ} \mathrm{W}\right)$ is closer to the coast and the time evolution of the vertical profile indicates larger amounts of Aitken mode aerosols towards the clouded area (Fig. 10, left panels). CRST_1 reaches 1400 particles $/ \mathrm{cm}^{3}$ comparable to PSO4_1, which 

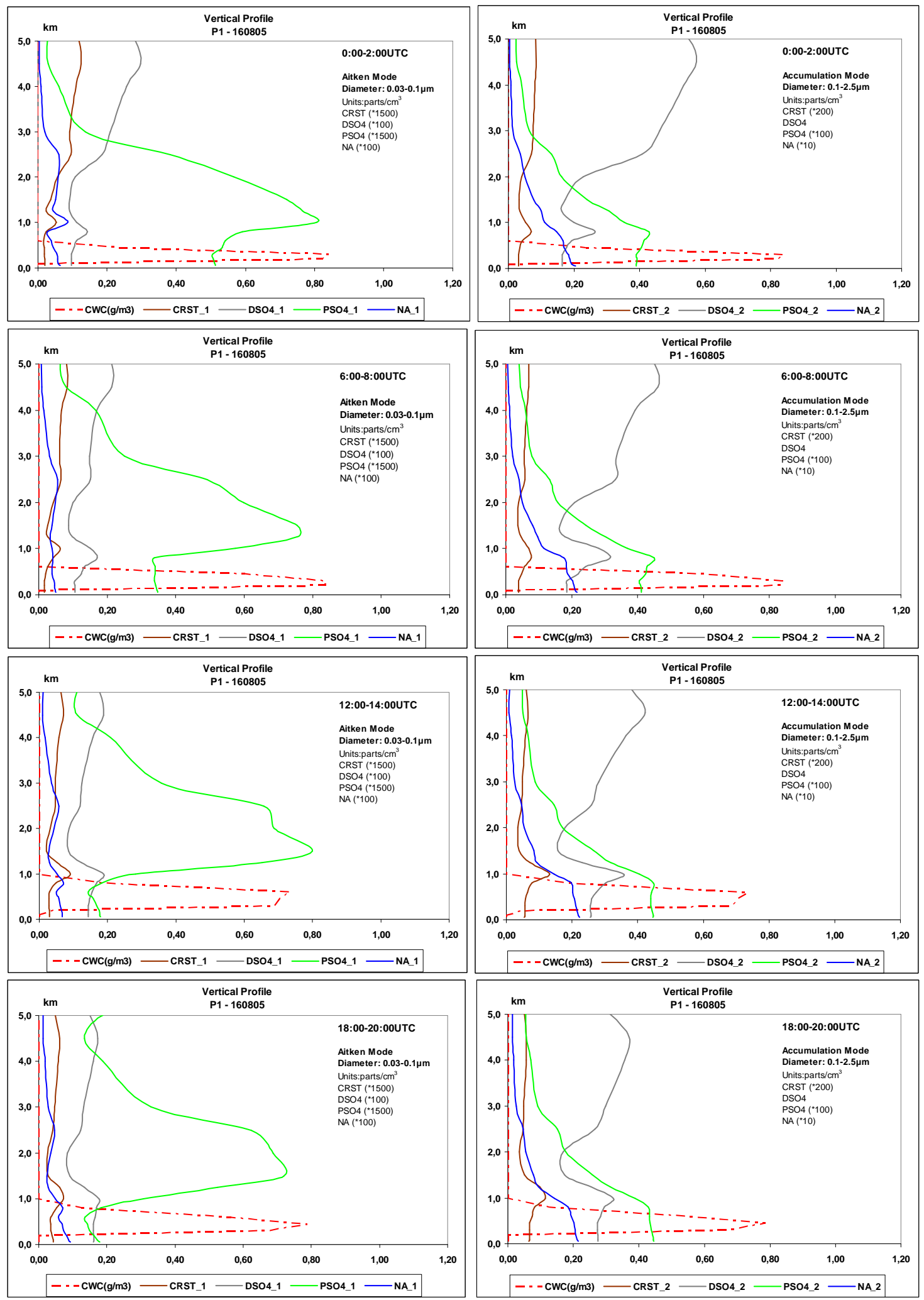

Fig. 9. Vertical profile of the condensed cloud water content $\mathrm{CWC}\left(\mathrm{g} / \mathrm{m}^{3}\right)$ and the aerosol number concentration (particles/ $\left.\mathrm{cm}^{3}\right)$ at location $\mathrm{P} 1$ (lat, lon $)=\left(23.5^{\circ} \mathrm{N}, 18.5^{\circ} \mathrm{W}\right)$. The left panels show the aerosols in the size section 1: $0.03-0.1 \mu \mathrm{m}$. The right panels show the aerosols in the size section 2: $0.1-2.5 \mu \mathrm{m}$. Day: 16 August 2005. 
Table 3. Typical ranges of number concentrations for desert dust, sulphates and sodium aerosols $\left(\mathrm{cm}^{-3}\right)$ in the vertical column of $0-5 \mathrm{~km}$. Model results for the 16 and 27 August 2005 ( $2 \mathrm{~h}$ average values).

\begin{tabular}{lllllllll}
\hline Location & CRST_1 & CRST_2 & DSO4_1 & DSO4_2 & PSO4_1 & PSO4_2 & NA_1 & NA_2 \\
\hline P1 & $\leq 188$ & $\leq 26$ & $\leq 30$ & $\leq 0.6$ & $42-1260$ & $\leq 45$ & $\leq 9$ & $\leq 2$ \\
P2 & $\leq 1400$ & $\leq 170$ & $\leq 24$ & $\leq 0.5$ & $82-\mathbf{1 4 6 0}$ & $\leq \mathbf{5 7}$ & $\leq \mathbf{1 2}$ & $\leq \mathbf{4}$ \\
P3 & $\leq 466$ & $\leq 77$ & $\leq 24$ & $\leq 0.46$ & $110-1400$ & $\leq 51$ & $\leq 9$ & $\leq 3$ \\
P4 & $2-\mathbf{1 4 3 0}$ & $\leq \mathbf{2 0 3}$ & $\leq 28$ & $\leq 0.6$ & $33-626$ & $\leq 14$ & $\leq 6$ & $\leq 1$ \\
P5 & $12-850$ & $3-84$ & $\leq \mathbf{3 8}$ & $\leq \mathbf{0 . 7}$ & $35-451$ & $\leq 33$ & $\leq 9$ & $\leq 3$ \\
P6 & $\leq 1400$ & $\leq 153$ & $\leq 33$ & $\leq 0.6$ & $40-519$ & $\leq 34$ & $\leq 12$ & $\leq 3$ \\
Other local maxima & 3000 & 600 & 47 & 0.9 & 5500 & 68 & 42 & 4
\end{tabular}

Notes: (1) The notation 1 refers to diameters $0.03-0.1 \mu \mathrm{m}$ and the notation 2 refers to diameters in the range $0.1-2.5 \mu \mathrm{m}$. (2) The "other" in the location column refers to generic maximum values of aerosol number density regardless of the location and time. (3) CRST=crustal material (desert dust), $\mathrm{DSO}_{4}=$ sulphate produced on dust surface, $\mathrm{PSO}_{4}=$ anthropogenic sulphate with the contribution of ss-sulphate, $\mathrm{NA}=$ sodium aerosol. (4) Maximum values for each species are denoted with bold font.

exhibits a maximum at about 1460 particles $/ \mathrm{cm}^{3}$ but not simultaneously with the non-sulphate-coated dust. The NA_1 maximum is approximately 12 particles $/ \mathrm{cm}^{3}$ near the cloud base and the DSO4_1 particles have only a limited vertical extent $\left(\max =24\right.$ particles $\left./ \mathrm{cm}^{3}\right)$. Both the desert dust and the anthropogenic sulphate aerosols in the Aitken mode can potentially influence the clouds at the top with high number concentrations, although the sulphate quickly decreases with time. In contrast, the accumulation mode sulphate decreases at a slower rate throughout the day. The sulphate aerosol in both modes exhibits a different vertical structure which can be explained from the different processes that govern each mode. The accumulation mode has a contribution from seasalt sulphate (not present in the smaller size section) which can explain the higher number concentration up to $1 \mathrm{~km}$ from the surface. In the Aitken mode, the sulphate aerosol exhibits a vertical layering throughout the previous day (15 August) which disappears at the beginning of the 16th. Since the species did not undergo wet deposition (absence of rain during that specific period from the atmospheric model SKIRON/Dust which has been verified with the TRMM $3 \mathrm{~h}$ rainfall archives), the main reasons for the different vertical structure can be the advection/diffusion process and consequently the long-range transport pattern and/or the nucleation process that assigns the nucleated mass to the first section of the distribution (the Aitken mode for this simulation). For the accumulation mode, the number density (Fig. 10, right panels) of CRST_2 reaches 170 particles $/ \mathrm{cm}^{3}$ at $800 \mathrm{~m}$ altitude, and the highest values for NA_2, PSO4_2, DSO4_2 are $4,57,0.5$ particles $/ \mathrm{cm}^{3}$, respectively. The transport of dust into the cloudy area seems to occur at the cloud top, whereas the other aerosol types mix in from below the cloud base, and their number density diminishes with height.

Location three $\mathrm{P} 3\left(\mathrm{lat}=23.5^{\circ} \mathrm{N}\right.$, lon $\left.=17.5^{\circ} \mathrm{W}\right)$ is also close to the coast and the time evolution of the vertical profile is quite similar to that at the previously discussed location for the accumulation mode (Fig. 11). Vertical profiles can be discerned for sulphates and desert dust, exhibiting a maximum mostly above the cloud top. The maximum values reached are 466, 9, 1400 and 24 particles $/ \mathrm{cm}^{3}$ for CRST_1, NA_1, PSO4_1 and DSO4_1, respectively (Fig. 11, left panels). Likewise, for the accumulation mode, the maximum values are 77, 2.7, 51 and 0.46 particles $/ \mathrm{cm}^{3}$ for CRST_2, NA_2, PSO4_2 and DSO4_2, respectively.

During the second selected day, 27 August 2005, cloud formation events were much less frequent near the Cape Verde region and along the West African coast. In general, the dense cloud formation during this day occurred mostly over the open ocean towards the west (western part of the domain in Fig. 6). The area investigated with the locations P4-P6 represents the entrance of the aerosols (mainly dust and sulphate on dust) into the oceanic region and in all locations the clouds are shallow. In location $\mathrm{P} 4$ (lat $=17.0^{\circ} \mathrm{N}$, lon $=17.0^{\circ} \mathrm{W}$ ), CRST_1 reaches 1430 particles $/ \mathrm{cm}^{3}$ (Fig. 12, left panels) and the CRST_2 maximum is 203 particles $/ \mathrm{cm}^{3}$ (Fig. 12, right panels). All other aerosol types have a lower number density compared to the conditions discussed above, with PSO4_1 being almost absent in the Aitken mode. Another important feature that differs from the previously discussed locations is the transport of dust. It typically occurs throughout the lower kilometres with a maximum towards the surface and a strong influence throughout the cloud layer, as the P4 location is very close to the continental outflow region.

The final two locations P5 (lat $=15.3^{\circ} \mathrm{N}$, lon $=22.5^{\circ} \mathrm{W}$ ) and P6 (lat $=17.0^{\circ} \mathrm{N}$, lon $=23.0^{\circ} \mathrm{W}$ ) are very close to the Cape Verde Islands. For both sites, we compute transport of desert dust towards the layers near the cloud top, with similar number concentrations for the accumulation and Aitken modes as those discussed previously (Figs. 13 and 14). $\mathrm{DSO}_{4}$ has the same vertical structure as mentioned earlier for dust, and is present at rather low number densities. The Saharan dust 
layer extends from approximately $500 \mathrm{~m}$ to $3 \mathrm{~km}$, in agreement with that reported by Formenti et al. (2003). The flight measurements by Formenti et al. (2003) took place in the same area during September 2000 and showed that the Saharan Air Layer (SAL) base was between 0.5 and $1 \mathrm{~km}$. The top of the layer reached $4-4.5 \mathrm{~km}$ in some locations. These findings and the ones in the present work are also in accord with Karyampudi et al. (1999) and Kallos et al. (2006). Anthropogenic sulphate $\left(\mathrm{PSO}_{4}\right)$ and sodium (NA) containing particles can influence the cloud formation from below the cloud base and their number density is lower than before for the sulphates and similar for the sodium aerosol. In terms of number distribution, the predominance of the Aitken mode over the accumulation mode is also a finding in common with Formenti et al. (2003) and Garrett and Hobbs (1995).

To summarize these findings, typical ranges of number concentrations for the different aerosol species for the six locations in the case studies are tabulated in Table 3. These ranges refer to the values occurring at the different vertical layers up to $5 \mathrm{~km}$, except for the last row. When the minimum number concentration was below one, the range of values was substituted by the less-equal sign. The common characteristic of the six locations is the appearance of clouds in the area. The last row in this table (named after "other" in the location column) indicates the maximum values for each aerosol type found in the area under investigation (small box in Fig. 8), regardless of the CWC amount. The values are indicative of the aerosols that can be found in this region throughout the period addressed by this modelling study. Typically, the Aitken mode $(0.03-0.1 \mu \mathrm{m})$ particle numbers dominate over the accumulation mode $(0.1-$ $2.5 \mu \mathrm{m})$. The Aitken number concentration ranges from 6 to 1400 particles $/ \mathrm{cm}^{3}$, depending on the aerosol type. The accumulation number concentration ranges from below 1 to approximately 200 particles $/ \mathrm{cm}^{3}$. These values refer to the selected locations P1-P6. When looking at the generic local maxima, the Aitken mode again dominates with a range of 42-5000 particles $/ \mathrm{cm}^{3}$ and the accumulation mode is in the range of approximately $1-600$ particles $/ \mathrm{cm}^{3}$. The most abundant species are desert dust and anthropogenic sulphate with comparable number densities in several cases. The third most important is sulphate on dust and the fourth sodium containing sea salt aerosol.

\section{Conclusions}

In this study we focused on aerosol number distributions of desert dust, sodium (representing sea salt), sulphate from anthropogenic sources and sulphate produced on the surface of dust particles in the Eastern-Central Atlantic Ocean area. The modelling results suggest that rather small amounts of accumulation mode desert dust, sodium and chemically aged mixed aerosols entered the region where tropical storms and/or hurricane genesis tends to take place (Central Atlantic
Ocean). Aerosols of smaller size (Aitken mode) are more abundant in the area and in some occasions sulphates of anthropogenic origin and desert dust are of the same order in terms of number concentration. Of all aerosols considered, desert dust and anthropogenic sulphate exhibit the highest mass and number concentrations although the other aerosol types are non-negligible as well. Additional findings include:

- Desert dust is present in the cloudy area with a maximum number density around 1400 particles $/ \mathrm{cm}^{3}$ in the Aitken mode $(0.03-0.1 \mu \mathrm{m})$ and 200 particles $/ \mathrm{cm}^{3}$ in the accumulation mode. These maximum values can be higher in the extended area, reaching 3000 particles $/ \mathrm{cm}^{3}$ and 600 particles $/ \mathrm{cm}^{3}$ in the Aitken and accumulation mode, respectively. The results are in good agreement with measurements by Formenti et al. (2003) for the Cape Verde region and Karyampudi et al. (1999) for the Saharan Air Layer. In addition, dust reaches the cloud layers mostly towards the cloud top, and sometimes throughout the lower atmosphere, especially close to the African coast. It is thus conceivable that in the case of storm development more remote from the coast, the dust enters the convective clouds in the active growth phase by entrainment above the boundary layer. Since this is a region where air parcels are likely to enter strong updrafts, the dust particles may serve as ice nuclei in the mixed cloud phase and can potentially affect the cloud water phase transitions and the latent energy budget.

- Sulphates of anthropogenic origin arrive at the Eastern and Central Atlantic Ocean region in significant amounts, reaching approximately 1400 particles $/ \mathrm{cm}^{3}$ in the Aitken mode and 60 particles $/ \mathrm{cm}^{3}$ in the accumulation mode. As with dust, these maximum values can be higher in the extended area, reaching 5500 particles $/ \mathrm{cm}^{3}$ and 70 particles $/ \mathrm{cm}^{3}$ in the Aitken and accumulation mode, respectively. Transport towards the stratiform cloud formation area can occur either near the top or the base of the clouds. This depends on the large scale transport component that leads the aerosols to travel either through or above the boundary layer. For the period of August, the Azores anticyclone typically governs the circulation in the area establishing a strong N-NE flow from Western Europe along the West African coastline. These air masses carry anthropogenic sulphate aerosols above the boundary layer (as can be seen in the locations P1-P3 during the 16th of August). On the contrary, when the anticyclonic system weakens and shifts slightly to the west (as occurred on the 27 August), the sulphate aerosols show a different vertical pattern with transport typically through the lower atmospheric layers up to $1 \mathrm{~km}$. In both cases the transported particles strongly enhance the number concentration of $\mathrm{CCN}$ as compared to non-polluted and non-dust influenced conditions. 

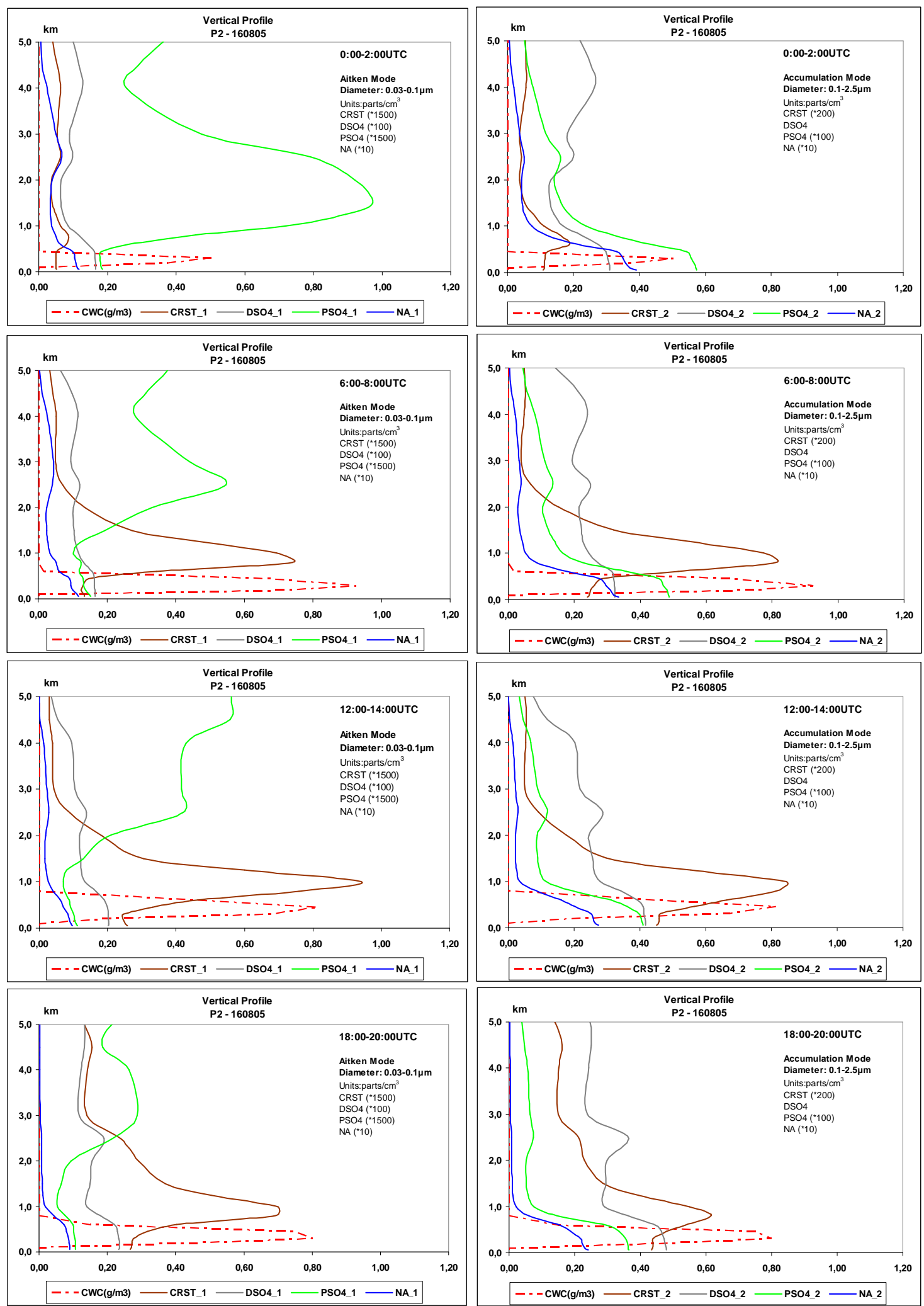

Fig. 10. Vertical profile of the condensed cloud water content $\mathrm{CWC}\left(\mathrm{g} / \mathrm{m}^{3}\right)$ and the aerosol number concentration (particles/ $\left.\mathrm{cm}^{3}\right)$ at location $\mathrm{P} 2$ (lat, lon) $=\left(21^{\circ} \mathrm{N}, 18.2^{\circ} \mathrm{W}\right)$. The left panels show the aerosols in the size section 1: 0.03-0.1 $\mu \mathrm{m}$. The right panels show the aerosols in the size section 2: 0.1-2.5 $\mu \mathrm{m}$. Day: 16 August 2005. 

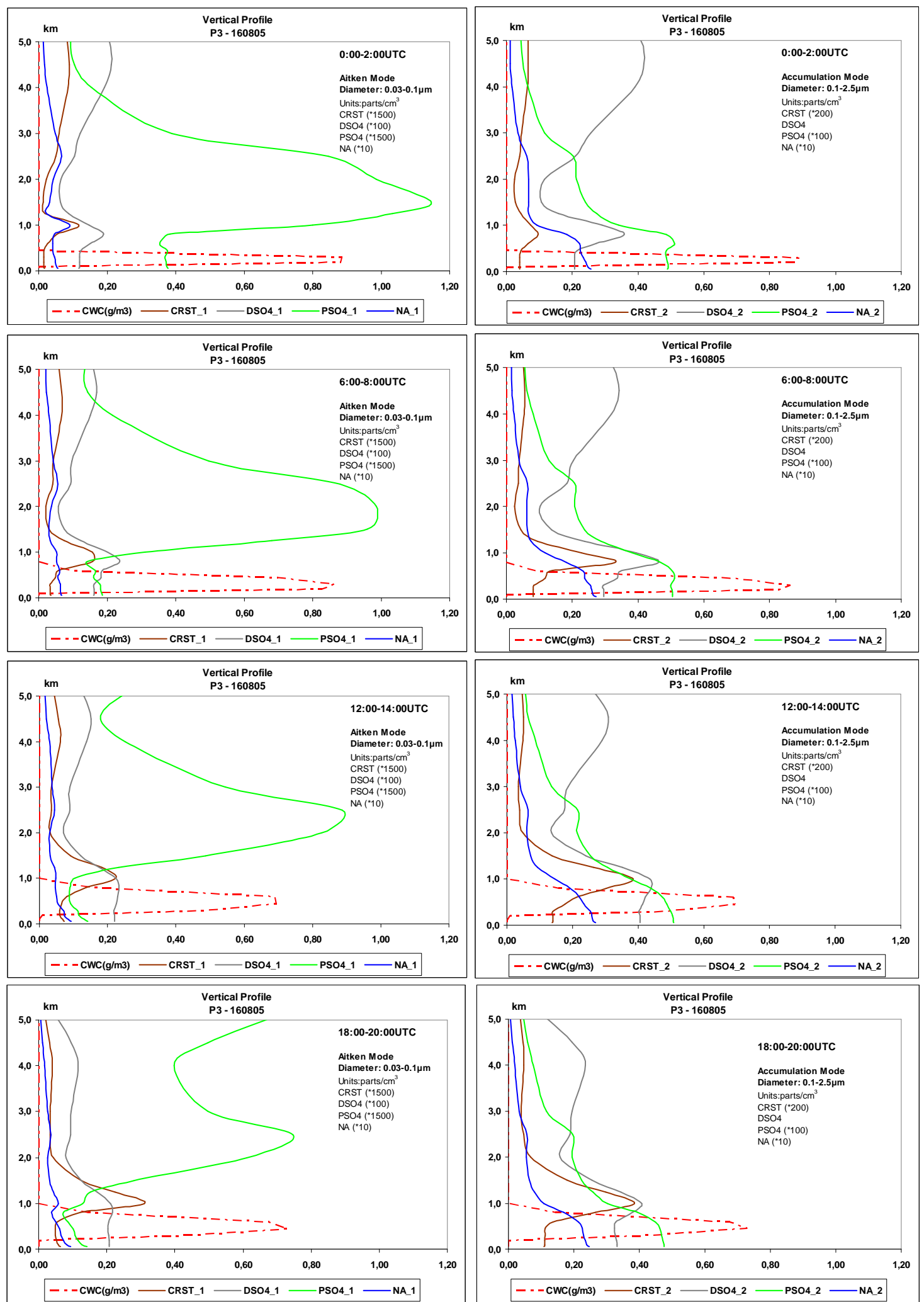

Fig. 11. Vertical profile of the condensed cloud water content $\mathrm{CWC}\left(\mathrm{g} / \mathrm{m}^{3}\right)$ and the aerosol number concentration (particles $/ \mathrm{cm}^{3}$ ) at location $\mathrm{P} 3$ (lat, lon $)=\left(23.5^{\circ} \mathrm{N}, 17.5^{\circ} \mathrm{W}\right)$. The left panels show the aerosols in the size section 1: $0.03-0.1 \mu \mathrm{m}$. The right panels show the aerosols in the size section 2: 0.1-2.5 $\mu$ m. Day: 16 August 2005. 

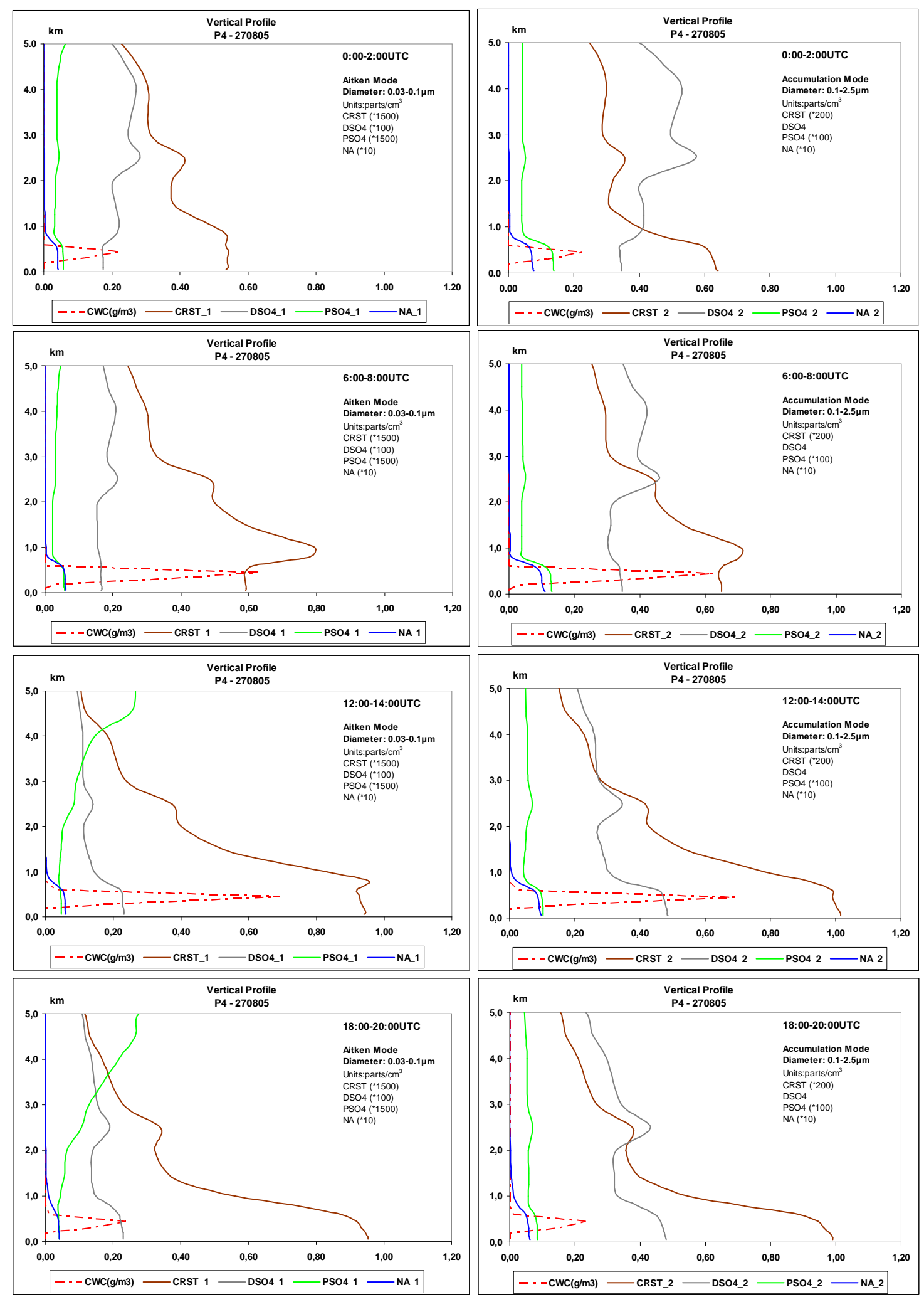

Fig. 12. Vertical profile of the condensed cloud water content $\mathrm{CWC}\left(\mathrm{g} / \mathrm{m}^{3}\right)$ and the aerosol number concentration (particles $\left./ \mathrm{cm}^{3}\right)$ at location $\mathrm{P} 4$ (lat, lon) $=\left(17^{\circ} \mathrm{N}, 17^{\circ} \mathrm{W}\right)$. The left panels show the aerosols in the size section 1: 0.03-0.1 $\mu \mathrm{m}$. The right panels show the aerosols in the size section 2: 0.1-2.5 $\mu \mathrm{m}$. Day: 27 August 2005. 

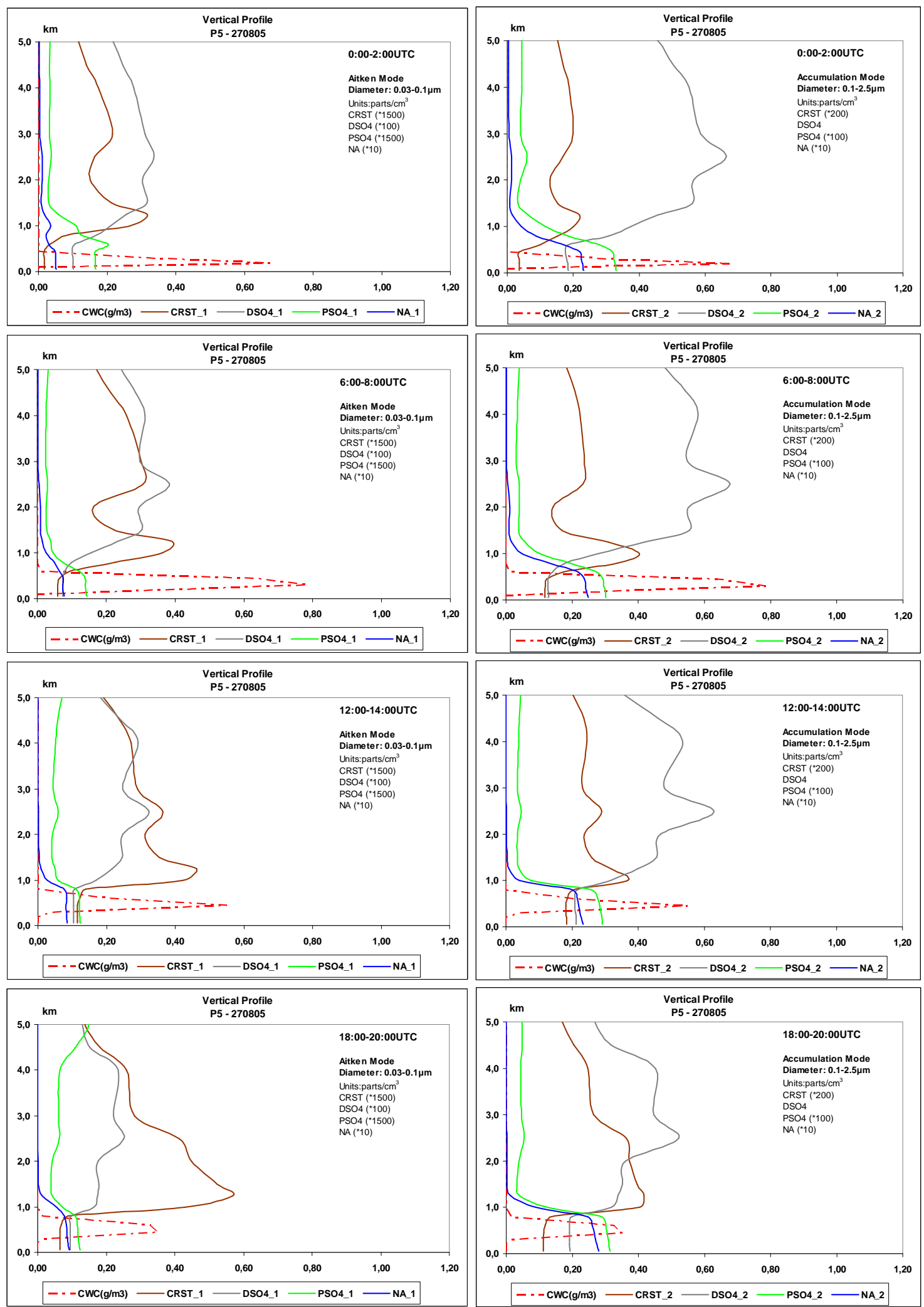

Fig. 13. Vertical profile of the condensed cloud water content $\mathrm{CWC}\left(\mathrm{g} / \mathrm{m}^{3}\right)$ and the aerosol number concentration (particles/ $\mathrm{cm}^{3}$ ) at location $\mathrm{P} 5$ (lat, lon $)=\left(15.3^{\circ} \mathrm{N}, 22.5^{\circ} \mathrm{W}\right)$. The left panels show the aerosols in the size section 1: 0.03-0.1 $\mu \mathrm{m}$. The right panels show the aerosols in the size section 2: 0.1-2.5 $\mu \mathrm{m}$. Day: 27 August 2005. 

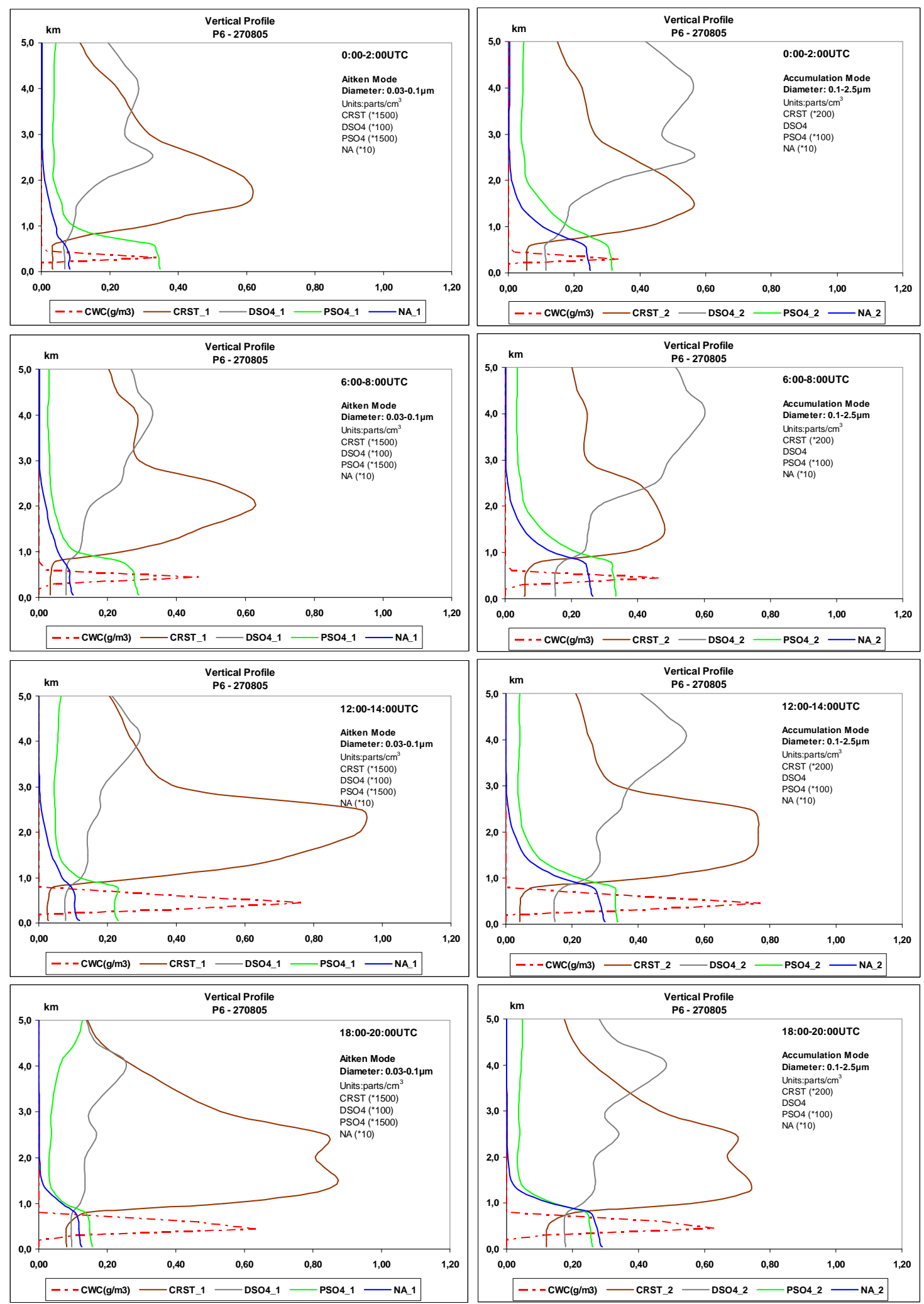

Fig. 14. Vertical profile of the condensed cloud water content $\mathrm{CWC}\left(\mathrm{g} / \mathrm{m}^{3}\right)$ and the aerosol number concentration (particles $\left./ \mathrm{cm}^{3}\right)$ at location P6 (lat, lon $)=\left(17^{\circ} \mathrm{N}, 23^{\circ} \mathrm{W}\right)$. The left panels show the aerosols in the size section 1: 0.03-0.1 $\mu \mathrm{m}$. The right panels show the aerosols in the size section 2: 0.1-2.5 $\mu \mathrm{m}$. Day: 27 August 2005. 
- Sulphates produced on dust particles exhibit relatively low number densities in the accumulation mode as they enter the Central Atlantic Ocean region, with no significant variability in their vertical distribution. In particular, the maximum percentage of sulphate produced on dust is $0.035 \%$ of the dust number distribution in the accumulation mode for the six studied locations, which is a rather small fraction. On the other hand, this aerosol type is represented by about 2040 particles $/ \mathrm{cm}^{3}$ in the Aitken mode, with maximum values reaching $\sim 50$ particles $/ \mathrm{cm}^{3}$. Sulphate on dust in the Aitken mode represents a percentage of the total dust number distribution ranging from $1 \%$ to $55 \%$ for the six studied locations and for number concentrations higher than 1 particle $/ \mathrm{cm}^{-3}$ (average maximum varies from $18 \%$ to $38 \%$ ). This result applies only to the methodology used for the current work and could potentially change by taking into account cloud-aerosol interactions, possibly leading to an increased number of coated dust particles as indicated in previous studies (Wurzler et al., 2000). The role of sulphate on dust in the Aitken mode can be important because it turns the particles from typically hydrophobic into hydrophillic so that they can also serve as efficient CCN. Transport occurs mostly through the upper atmospheric layers and rarely through the lower layers, following the dust movement in the area.

- Sodium containing sea salt aerosol is found to have relatively small accumulation mode number concentrations (maximum $\sim 5$ particles $/ \mathrm{cm}^{3}$ ) and relatively higher Aitken mode number concentrations (maximum $\sim 40$ particles $/ \mathrm{cm}^{3}$ ). The sea salt particles reach the cloud formation area at the cloud base in all cases as they are generated from below.

In general, aerosols with different chemical composition and size reach the Eastern and Central Atlantic cloudy region in different vertical layers. The size and composition is related to the origin of the air masses (anthropogenic or natural sources) and the transformations occurring during transport. The aerosol mixture, hygroscopicity (CCN and IN properties) and the altitude at which they arrive may crucially influence the microphysics and the life cycle of different cloud types.

\section{Appendix A}

In the statistical metrics described below, the modelled mass concentration is represented by $C_{m}$, the observed concentration by $C_{o}$ and $N$ is the total number of data points used in the calculations.
- Root Mean Square Error (RMSE):

$$
\mathrm{RMSE}=\sqrt{\frac{1}{N} \sum_{N}\left(C_{m}-C_{o}\right)^{2}}
$$

- Mean Bias (MB):

$$
\mathrm{MB}=\frac{1}{N} \sum_{N}\left(C_{m}-C_{o}\right)
$$

- Mean Absolute Gross Error (MAGE):

$$
\mathrm{MAGE}=\frac{1}{N} \sum_{N}\left|C_{m}-C_{o}\right|
$$

- Normalized Mean Bias (NMB):

$$
\mathrm{NMB}=\frac{\sum_{N}\left(C_{m}-C_{o}\right)}{\sum_{N} C_{o}} \times 100 \%
$$

- Normalized Mean Error (NME):

$$
\mathrm{NME}=\frac{\sum_{N}\left|C_{m}-C_{o}\right|}{\sum_{N} C_{o}} \times 100 \%
$$

- Fractional Bias (FB):

$$
\mathrm{FB}=\frac{2}{N} \sum_{N}\left(\frac{C_{m}-C_{o}}{C_{m}+C_{o}}\right) \times 100 \%
$$

- Fractional Error (FE):

$$
\mathrm{FB}=\frac{2}{N} \sum_{N}\left(\frac{\left|C_{m}-C_{o}\right|}{C_{m}+C_{o}}\right) \times 100 \%
$$

- Percentage within a factor of 2 (FAC2):

The fraction of points within 0.5 and 2 times the observations. $0.5 \leq \frac{C_{m}}{C_{o}} \leq 2.0$

\section{Supplementary material related to this article is available online at: http://www.atmos-chem-phys.net/10/5797/2010/ acp-10-5797-2010-supplement.pdf.}

Acknowledgements. We would like to thank Wolfram Birmili (Leibniz Institute of Tropospheric Research) for providing the datasets of aerosol measurements for the Meplitz and Zugspitze stations. We acknowledge the contribution from the Co-operative Programme for Monitoring and Evaluation of the Long-range Transmission of Air Pollutants in Europe (EMEP) and the European Environment Agency Airbase public air quality database for providing measurements of $\mathrm{PM}_{10}$ and $\mathrm{PM}_{2.5}$. The authors would like to acknowledge the contribution of the European Union (CIRCE project-contract \#036961) and the European Research Council (C8 project).

Edited by: X. Querol

\section{References}

Alpert, P., Kaufman, Y. J., Shay-El, Y., Tanre, D., da Silva, A., Schubert, S., and Joseph, J. H.: Quantification of dust-forced heating of the lower troposphere, Nature, 395, 367-370, 1998. 
Andreae, M. O., Charlson, R. J., Bruynseels, F., Storms, H., Van Grieken, R., and Maenhaut, W.: Internal Mixture of Sea Salt, Silicates, and Excess Sulfate in Marine Aerosols, Science, 232, 1620-1623, doi:10.1126/science.232.4758.1620, 1986.

Andreae, M. O., Hegg, D. A., and Baltensperger, U.: Sources and Nature of Atmospheric Aerosols, Chapter 3 in Aerosol Pollution Impact on Precipitation-A Scientific Review, edited by: Levin, Z. and Cotton, W. R., Springer, ISBN: 978-1-4020-8689-2, 2009.

Astitha, M. and Kallos, G.: Gas-phase and aerosol chemistry interactions in South Europe and the Mediterranean Region, Environmental Fluid Mechanics, 9(1), 3-22, doi:10.1007/s10652008-9110-7, 2009.

Astitha, M., Kallos, G., and Katsafados, P.: Air Pollution Modeling in the Mediterranean Region: From Analysis of Episodes to Forecasting, Atmos. Res., 89, 358-364, 2008.

Bauer, S. E., Balkanski, Y., Schulz, M., Hauglustaine, D. A., and Dentener F.: Global modeling of heterogeneous chemistry on mineral aerosol surfaces: Influence on tropospheric ozone chemistry and comparison to observations, J. Geophys. Res., 109, D02304, doi:10.1029/2003JD003868, 2004.

Bauer, S. E. and Koch, D.: Impact of heterogeneous sulfate formation at mineral dust surfaces on aerosol loads and radiative forcing in the Goddard Institute for Space Studies general circulation model, J. Geophys. Res., 110(D17), D17202, doi:10.1029/2005JD005870, 2005.

Birmili, W., Ries, L., Sohmer, R., Anastou, A., Sonntag, A., König, K., and Levin, I.: Fine and ultrafine aerosol particles at the GAW station Schneefernerhaus/Zugspitze, Gefahrst. Reinh. Luft, 69(1/2), 31-35, 2009a.

Birmili, W., Weinhold, K., Nordmann, S., Wiedensohler, A., Spindler, G., Müller, K., Herrmann, H., Gnauk, T., Pitz, M., Cyrys, J., Flentje, H., Nickel, C., Kuhlbusch, T. A. J., Löschau, G., Haase, D., Meinhardt, F., Schwerin, A., Ries, L., and Wirtz, K.: Atmospheric aerosol measurements in the German Ultrafine Aerosol Network (GUAN): Part 1 - soot and particle number size distributions, Gefahrst. Reinh. Luft, 69(4), 137-145, 2009 b.

Cozic, J., Verheggen, B., Weingartner, E., Crosier, J., Bower, K. N., Flynn, M., Coe, H., Henning, S., Steinbacher, M., Henne, S., Collaud Coen, M., Petzold, A., and Baltensperger, U.: Chemical composition of free tropospheric aerosol for $\mathrm{PM}_{1}$ and coarse mode at the high alpine site Jungfraujoch, Atmos. Chem. Phys., 8, 407-423, doi:10.5194/acp-8-407-2008, 2008.

Denman, K. L., Brasseur, G., Chidthaisong, A., Ciais, P., Cox, P. M., Dickinson, R. E., Hauglustaine, D., Heinze, C., Holland, E., Jacob, D., Lohmann, U., Ramachandran, S., da Silva Dias, P. L., Wofsy S. C. and Zhang, X.: Couplings Between Changes in the Climate System and Biogeochemistry. In: Climate Change 2007: The Physical Science Basis. Contribution of Working Group I to the Fourth Assessment Report of the Intergovernmental Panel on Climate Change, edited by: Solomon, S., Qin, D., Manning, M., Chen, Z., Marquis, M., Averyt, K. B., Tignor, M., and Miller, H. L., Cambridge University Press, Cambridge, United Kingdom and New York, NY, USA, 2007.

de Reus, M., Fischer, H., Sander, R., Gros, V., Kormann, R., Salisbury, G., Van Dingenen, R., Williams, J., Zöllner, M., and Lelieveld, J.: Observations and model calculations of trace gas scavenging in a dense Saharan dust plume during MINATROC, Atmos. Chem. Phys., 5, 1787-1803, doi:10.5194/acp-5-17872005, 2005.
Dentener, F. J., Carmichael, G. R., Zhang, Y., Lelieveld, J., Crutzen, P.: Role of mineral aerosol as a reactive surface in the global troposphere, J. Geophys. Res., 101(D17), 22869-22889, 1996.

Dusek, U., Frank, G. P., Hildebrandt, L., Curtius, J., Schneider, J., Walter, S., Chand, D., Drewnick, F., Hings, S., Jung, D., Borrmann, S., and Andreae M. O.: Size Matters More Than Chemistry for Cloud-Nucleating Ability of Aerosol Particles, Science, 312(5778), 1375, doi:10.1126/science.1125261, 2006.

Engler, C., Rose, D., Wehner, B., Wiedensohler, A., Brüggemann, E., Gnauk, T., Spindler, G., Tuch, T., and Birmili, W.: Size distributions of non-volatile particle residuals $\left(\mathrm{D}_{\mathrm{p}}<800 \mathrm{~nm}\right)$ at a rural site in Germany and relation to air mass origin, Atmos. Chem. Phys., 7, 5785-5802, doi:10.5194/acp-7-5785-2007, 2007.

Environ: User's Guide to the Comprehensive Air Quality Model with Extensions (CAMx), Version 4. 31, prepared by ENVIRON Inter. Corp., Novato, CA, 2006.

EPA: Guidance on the Use of Models and Other Analyses for Demonstrating Attainment of Air Quality Goals for Ozone, $\mathrm{PM}_{2.5}$, and Regional Haze, US Environmental Protection Agency, Office of Air Quality Planning and Standards, Air Quality Analysis Division, Research Triangle Park, North Carolina, EPA-454/B-07-002, April 2007.

Evan, A. T., Dunion, J., Foley, J. A., Heidinger, A. K., and Velden, C. S.: New evidence for a relationship between Atlantic tropical cyclone activity and African dust outbreaks, Geophys. Res. Lett., 33, L19813, doi:10.1029/2006GL026408, 2006.

Evan, A., Vimont, D., Heidinger, A., Kossin, J., and Bennartz, R.: The role of aerosols in the evolution of Tropical North Atlantic Ocean Temperature Anomalies, Science, 324, 778-781, 2009.

Feingold, G., Cotton, W. R., Kreidenweiss, S. M., and Davis, J. T.: The impact of giant cloud condensation nuclei on drizzle formation in stratocumulus: Implications for cloud radiative properties, J. Atmos. Sci., 56, 4100-4117, 1999.

Formenti, P., Elbert, W., Maenhaut, W., Haywood, J., and Andreae, M. O.: Chemical composition of mineral dust aerosol during the Saharan Dust Experiment (SHADE) airborne campaign in the Cape Verde region, September 2000, J. Geophys. Res., 108(D18), 8576, doi:10.1029/2002JD002648, 2003.

Forster, P., Ramaswamy, V., Artaxo, P., Berntsen, T., Betts, R., Fahey, D. W., Haywood, J., Lean, J., Lowe, D. C., Myhre, G., Nganga, J., Prinn, R., Raga, G., Schulz, M., and Van Dorland R.: Changes in Atmospheric Constituents and in Radiative Forcing. In: Climate Change 2007: The Physical Science Basis. Contribution of Working Group I to the Fourth Assessment Report of the Intergovernmental Panel on Climate Change, edited by: Solomon, S., Qin, D., Manning, M., Chen, Z., Marquis, M., Averyt, K. B., Tignor, M., and Miller, H. L., Cambridge University Press, Cambridge, United Kingdom and New York, NY, USA, 2007.

Fuchs, N. A. and Sutugin, A. G.: Highly dispersed aerosols, Ann Arbor Science Publishers, Ann Arbor, MI, 1970.

Gangoiti, G., Alonso, L., Navazo, M., García, J. A., and Millan, M. M.: North African soil dust and European pollution transport to America during the warm season: Hidden links shown by a passive tracer simulation, J. Geophys. Res., 111, D10109, doi:10.1029/2005JD005941, 2006.

Garrett, T. J. and Hobbs, P. V.: Long range transport of continental aerosols over the Atlantic Ocean and their effects on cloud structures, J. Atmos. Sciences, 52(16), 2977-2984, 1995. 
Goodman, A. L., Li, P., Usher, C. R., and Grassian, V. H.: Heterogeneous uptake of sulfur dioxide on aluminum and magnesium oxide particles, J. Phys. Chem. A, 105, 6109-6120, 2001.

Husar, R. B., Prospero, J., and Stowe, L.: Characterization of tropospheric aerosols over the oceans with the NOAA advanced very high resolution radiometer optical thickness operational product, J. Geophys Res., 102(D14), 16889-16909, 1997.

Kallos, G., Nickovic, S., Papadopoulos, A., Jovic, D., Kakaliagou, O., Misirlis, N., Boukas, L., Mimikou, N., Sakellaridis, G., Papageorgiou, J., Anadranistakis, E., and Manousakis, M.: The regional weather forecasting system SKIRON: An overview, Proceedings of the International Symposium on Regional Weather Prediction on Parallel Computer Environments, ISBN: 9608468-22-1, University of Athens, Greece, 109-122, 1997.

Kallos, G., Kotroni, V., Lagouvardos, K., and Papadopoulos A.: On the long-range transport of air pollutants from Europe to Africa, Geophys. Res. Lett., 25(5), 619-622, 1998.

Kallos, G., Papadopoulos, A., Katsafados, P., and Nickovic, S.: Trans-Atlantic Saharan dust transport: Model simulation and results, J. Geophys. Res., 111, D09204, doi:10.1029/2005JD006207, 2006.

Kallos, G., Astitha, M., Katsafados, P., and Spyrou, C.: LongRange Transport of Anthropogenically and Naturally Produced Particulate Matter in the Mediterranean and North AtlanticCurrent State of Knowledge, J. Applied Meteor. Climat., 46(8), 1230-1251, 2007.

Kallos, G., Spyrou, C., Astitha, M., Mitsakou, C., Solomos, S., Kushta, J., Pytharoulis, I., Katsafados, P., Mavromatidis, E., and Papantoniou, N.: Ten-year operational dust forecasting - Recent model development and future plans, IOP Conf. Ser.: Earth Environ. Sci., 7, 012012, doi:10.1088/1755-1307/7/1/012012, 2009.

Karyampudi, V. M.: A detailed synoptic-scale study of the structure, dynamics, and radiative effects of the Saharan air layer over the eastern tropical Atlantic during GARP Atlantic Tropical Experiment, MS thesis, Department of Meteorology, The Pennsylvania State University, 136 pp., 1979.

Karyampudi, V. M., Palm, S. P., Reagen, J. A., and Coauthors: Validation of the Saharan dust plume conceptual model using lidar, Meteosat, and ECMWF data, B. Am. Meteor. Soc., 80, 10451075, 1999.

Kaufman, Y. J., Tanre, D., Mattoo, S., Eck, T. F., Vaughan, J., Chatenet, B., Holben, B. N., Remer, L. A.: Aerosol radiative impact on spectral solar flux at the surface, derived from principalplane sky measurements, J. Atmos. Sci., 59, 635-646, 2002a.

Kaufman, Y. J., Tanre, D., and Boucher, O.: A satellite view of aerosols in the climate system, Nature, 419, 215-223, 2002b.

Lau, W. K. M. and Kim, K. M.: How Nature Foiled the 2006 Hurricane Forecasts, Eos Trans. AGU, 88(9), 105-107, 2007.

Lelieveld, J., Berresheim, H., Borrmann, S., Crutzen P. J., and Coauthors: Global air pollution crossroads over the Mediterranean, Science, 298, 794-799, 2002.

Levin, Z., Ganor, E., and Gladstein, V.: The Effects of Desert Particles Coated with Sulfate on Rain Formation in the Eastern Mediterranean, J. Appl. Meteor., 35, 1511-1523, 1996.

Levin, Z., Teller, A, Ganor, E., and Yin, Y.: On the interactions of mineral dust, sea-salt particles and clouds: a measurement and modelling study from the Mediterranean Israeli Dust Experiment campaign, J. Geophys. Res., 110, D20202, doi:10.1029/2005JD005810, 2005.
Levin, Z. and Cotton, W. R.: Aerosol Pollution Impact on Precipitation-A Scientific Review, Springer, 386 pp., ISBN: 9781-4020-8689-2, 2009.

Millan, M. M., Salvador, R., Mantilla, E., and Kallos, G.: Photooxidant dynamics in the western Mediterranean in summer: Results from European research projects, J. Geophys. Res., 102(D7), 8811-8823, 1997.

Nenes, A., Pilinis, C., and Pandis, S. N.: ISORROPIA: A new thermodynamic model for multiphase multicomponent inorganic aerosols, Aquat. Geochem., 4, 123-152, 1998.

Nickovic, S., Kallos, G., Papadopoulos, A., and Kakaliagou, O.: A model for prediction of desert dust cycle in the atmosphere, J. Geophys. Res., 106, 18113-18129, 2001.

Perez, C., Nickovic, S., Pejanovic, G., Baldasano, J. M., and Özsoy E.: Interactive dust radiation modeling: A step to improve weather forecasts, J. Geophys. Res., 111, D16206, doi:10.1029/2005JD006717, 2006.

Perry, K. D., Cahill, T. A., Eldred, R. A., and Dutcher, D. D.: Longrange transport of North African dust to the eastern Union States, J. Geophys. Res., 102, 11225-11238, 1997.

Prospero, J. M., Olmez, I., and Ames, M.: Al and Fe in $\mathrm{PM}_{2.5}$ and $\mathrm{PM}_{10}$ suspended particles in South-Central Florida: The impact of the long range transport of African mineral dust, Water Air Soil Pollut., 125, 291-317, 2001.

Ramanathan, V., Crutzen, P. J., Kiehl, J. T., Rosenfeld, D.: Aerosols, Climate and the Hydrological Cycle, Science, 294, 2119, doi:10.1126/science.1064034, 2001.

Redelsperger, J.-L., Thorncroft, C. D., Diedhiou, A., Lebel, T., Parker, D. J., and Polcher J.: African Monsoon Multidisciplinary Analysis: An international research project and field campaign, B. Am. Meteor. Soc., 87, 1739-1746, 2006.

Remer, L. A., Tanré, D., and Kaufman, Y.: Algorithm for remote sensing of tropospheric aerosol from MODIS: collection 5. MODIS Algorithm Theoretical Basis Document. 87 pp. Available at: http://modis-atmos.gsfc.nasa.gov/MOD04_L2/ atbd.html, 2006.

Saylor, R. D.: An estimate of the potential significance of heterogeneous loss to aerosols as an additional sink for $\mathrm{HO}$ radicals in the troposphere, Atmos. Environ., 21, 3653-3658, 1997.

Seinfeld, J. and Pandis, S.: Atmospheric Chemistry and Physics (From Air Pollution to Climate Change), John Wiley and Sons, Inc., 2nd edition, 2006.

Spyrou, C., Mitsakou, C., Kallos, G., Louka, P., and Vlastou, G.: An improved limited-area model for describing the dust cycle in the atmosphere, J. Geophys. Res., doi:10.1029/2009JD013682, in press, 2010.

Tang, Y., Carmichael, G. R., Kurata, G., Uno, I., Weber, R. J., Song, C., Guttikunda, S. K., Woo, J. H., Streets, D. G., Wei, C., Clarke, A. D., Huebert, B., and Anderson, T. L.: Impacts of dust on regional tropospheric chemistry during the ACE-Asia experiment: A model study with observations. J. Geophys. Res., 109, D19S21, doi:10.1029/2003JD003806, 2004.

Teller, A. and Levin, Z.: The effects of aerosols on precipitation and dimensions of subtropical clouds: a sensitivity study using a numerical cloud model, Atmos. Chem. Phys., 6, 67-80, doi:10.5194/acp-6-67-2006, 2006.

Usher, C. R., Al-Hosney, H., Carlos-Cuellar, S., and Grassian, V. H.: A laboratory study of the heterogeneous uptake and oxidation of sulfur dioxide on mineral dust particles, J. Geophys. Res.-A, 
107, 4713, doi:10.1029/2002JD002051, 2002.

Vestreng, V.: EMEP/MSC-W Technical report. Review and Revision. Emission data reported to CLRTAP. MSC-W Status Report 2003, EMEP/MSC-W Note 1/2003, ISSN 0804-2446, 2003.

Visschedijk, A. H. J. and Denier van der Gon, H. A. C.: Gridded European anthropogenic emission data for $\mathrm{NO}_{\mathrm{x}}, \mathrm{SO}_{2}, \mathrm{NMVOC}$, $\mathrm{NH}_{3}, \mathrm{CO}, \mathrm{PM}_{10}, \mathrm{PM}_{2.5}$ and $\mathrm{CH}_{4}$ for the year 2000, TNO B\&OA Rapport 2005/106, $2^{\text {nd }}$ version November, 2005.

Wurzler, S., Reisin, T., and Levin, Z.: Modification of mineral dust particles by cloud processing and subsequent effects on drop size distributions, J. Geophys. Res., 105(D4), 4501-4512, doi:10.1029/1999JD900980, 2000.

Yin, Y., Levin, Z., Reisin, T. G., and Tzivion, S.: The effects of giant cloud condensation nuclei on the development of precipitation in convective clouds-a numerical study, Atmos. Res., 53, 91-116, 2000 .
Zhang, Y. and Carmichael, G. R.: The role of mineral aerosol in tropospheric chemistry in East Asia-A model study, J. App. Met., 38, 353-366, 1999.

Zhang, Y., Sunwoo, Y., Kotamarthi, V., and Carmichael, G. R.: Photochemical oxidant pro-processes in the presence of dust: An evaluation of the impact of dust on particulate nitrate and processes ozone formation, J. Appl. Met., 33, 813-824, 1994.

Zipser, E. J, Twohy, C. H., Tsay, S., Thornhill, K. L., Tanelli, S., Ross, R., Krishnamurti, T. N., Ji, Q., Jenkins, G., Ismail, S., Hsu, N. C., Hood, R., Heymsfield, G. M., Heymsfield, A., Halverson, J., Goodman, H. M., Ferrare, R., Dunion, J. P., Douglas, M., Cifelli, R., Chen, G., Browell, E. V., and Anderson, B.: The Saharan Air Layer and the Fate of African Easterly Waves NASA's AMMA Field Study of Tropical Cyclogenesis, B. Am. Meteor. Soc., 90(8), 1137-1156, 2009. 